\title{
DIE SUID-AFRIKAANSE OORLOGSEKONOMIE GEDURENDE DIE TWEEDE WÊRELDOORLOG - DEEL I
}

Deur Mnr J vd B Breedt*

\author{
There is a vast difference between the economies of a country during peace-time and a country \\ at war. \\ This article (to be published in two parts) analyses the South African economy during the \\ Second World War with special reference to the changes and adaptation that it underwent from a \\ peace-time to a war-time economy.
}

\begin{abstract}
Inleiding - Die situasie vooraf
Hierdie is ' $n$ poging om die Suid-Afrikaanse ekonomiese verloop gedurende die Tweede Wêreldoorlog te analiseer en te beskryf, dws die aanpassing wat dit ondergaan het vanaf ' $n$ normale vredestydse- na 'n oorlogsekonomie.
\end{abstract}

Die begrip oorlogsekonomie benodig verdere omskrywing. Dit kan beskryf word as ' $n$ tipe ekonomiese stelsel wat in 'n staat aangetref word wanneer hy militêr-georiënteerd is, of daarin gedwing word indien die betrokke land in 'n oorlogsituasie gewikkel is, dws waar die ekonomiese struktuur hoofsaaklik gebaseer is op die produksie van oorlogsmateriaal, en die voorsiening van siviele behoeftes of ' $n$ oorlewingspotensiaal aan die burgerlike bevolking slegs tweede prioriteit inneem.

Dit kom dus daarop neer dat ' $n$ vry mark-ekonomie in oorlogstyd omskep moet word in 'n beplande ekonomie waarin die owerheid beheer oor alle hulpbronne van die land moet neem ten einde die produksie te handhaaf om die oorlog te wen. Dis welbekend dat die wapens vir 'n totale oorlog militêr, ekonomies, maatskaplik en sielkundig is. Vir die doel hiervan moet aanvaar word dat die aanwending van alle bronne in oorlogstyd 'n ekonomiese inslag het, en die militêre probleem globaal gesien dus nie van die ekonomiese probleem, skaarsheid van bronne, ontkoppel kan word nie.

Ten einde die posisie volledig te kan analiseer en begryp is dit gerade om die Suid-Afrikaanse ekonomie in die jare onmiddellik voor die Tweede Wêreldoorlog in oënskou te neem. Die benadering hiervan sal deurgaans eerder ekonomies-analities as histories wees met die oog daarop om die student in ekonomie te prikkel tot moontlike toepassing hiervan op die huidige en toekomstige situasies. Om hierdie redes sal in hierdie gedeelte vooraf slegs gekonsentreer word op die een dekade onmiddellik voor die Tweede Wêreldoorlog, naamlik die dertigerjare.

By ' $n$ beskouing van die ekonomiese situasie in Suid-Afrika voor WO II kan nie anders as begin word by mynwese en in die besonder die aandeel en bydrae van die goudmyne hiertoe nie. Dit is ' $n$ welbekende feit dat die goudmynindustrie 'n dominante plek in die SA ekonomie beklee het (en nog steeds beklee), gemeet in terme nie alleen van bydrae tot die volksproduk nie maar ook tot die staatsinkomste, buitelandse handel en ander sektore van ekonomiese aktiwiteit, sowel as die aanlokking van kapitaal en kundigheid in die vorm van ondernemers- en geskoolde arbeid uit die buiteland.

Die bydrae van die goudmyne tot die volksproduk het van $12,7 \%$ in $1929-30$ tot $18,4 \%$ in 1938-39, terwyl die geskatte volksproduk oor dieselfde tydperk van R470 miljoen tot R784 toegeneem het. ${ }^{1}$ Syfers toon dat produksie in die nywerheidsektor vinniger as in die mynwese oor hierdie tydperk gegroei het, hoewel dit natuurlik vanaf ' $n$ laer basis as by mynwese was. Bogenoemde syfers toon duidelik die hoë bydrae sowel as die toename in bydrae van die goudmynnywerheid tot die totale volksproduk oor hierdie tydperk, wat deels die gevolg was van die styging in die goudprys met die afstapping van die goudstandaard en die gepaardgaande stimulasie-effek daarvan.

Die bydrae van die goudmyne tot die buitelandse handel is ook goed bekend. Oor die tydperk 1931-38 het goud in waarde gemiddeld meer as $70 \%$ tot die totale SA uitvoere bygedra, ${ }^{2}$ terwyl die voorrade meestal binnelands verkry is, sodat globaal gesien, die goudmyne die grootste verskaffer van buitelandse valuta aan die ander sektore ter finansiering van hulle buitelandse behoeftes was. 
Die goudmyne se bydrae tot die staatskas was en bly natuurlik nie alleen in die vorm van direkte belasting op winste (wat hoër is as by ander maatskappye nie) dog ook in die vorm van huurpag en ander regte. Soos te wagte is, het kapitaalbelegging in die goudmyne oor hierdie vooroorlogse dekade geweldig gestyg, en terselfdertyd het totale indiensneming in goudmyne van 221,204 in 1930 tot 343,905 in 1939 toegeneem. ${ }^{3}$.

By die vooroorlogse ekonomie van Suid-Afrika beklee die landbousektor histories sowel as ekonomies- maatskaplik ' $n$ baie belangrike plek. Juis vir die oorskakeling van 'n vredestydse na 'n oorlogsekonomie- en terugskakeling na-oorlogs in die teenoorgestelde rigting - bly die landbousektor ook van kardinale belang in enige volkshuishouding. In Suid-Afrika se geval temeer so, omdat die langbou nie alleen histories die oudste bedryfstak is nie, maar landbou ook nog altyd beskou was as 'n lewenswyse. Die rol van die landbou in die Suid-Afrikaanse ekonomiese-, politieke en sosiale lewe is algemeen bekend, maar ' $n$ waardering daarvan kan nie net uit blote syfers alleen gemaak word nie. Dit is bekend dat volgens die 1936 -sensusgegewens $35 \%$ van die blankes en $78 \%$ anderskleuriges as landelik geklassifiseer en twee-derdes van alle ekonomies-aktiewes in die landbou betrek was.

Wanneer gelet word op die vooroorlogse landboupotensiaal is ' $n$ welbekende feit die lae produktiwiteit van die Suid-Afrikaanse landbou beide wat gewasverbouing en veeteelt betref, in vergelyking met ander lande, wat hoofsaaklik te wyte is aan lae reënval en ander natuurlike beperkings, sowel as hoë bemarkingskoste en ander ekonomiese beperkings. Suid-Afrika was daarom voor Wêreldoorlog I 'n netto invoerder van belangrike voedselsoorte. Agv skaarstes het hoë pryse gedurende en na die oorlog produksie gestimuleer, dog die gevolge van die droogte en wêrelddepressie 1929-33 het die bedryf nadelig getref. Deur middel van die bemarkingswet van 1937 en ander doelbewuste hulpmaatreëls het die owerheid egter daarin geslaag om die landboubedryf sodanig te bevorder dat SuidAfika van ' $n$ netto-invoerder van basiese voedselsoorte tot feitlik selfversorgendheid en ' $n$ netto uitvoerder van belangrike landbousurplusse soos suiker, mielies, vrugte, velle en wol in onverwerkte vorm gedurende hierdie vooroorlogse dekade ontwikkel het. Oor 'n betreklike kort tydperk het die produksie van mielies en koring meer as verdubbel, met ooreenkomstige uitbreidings in alle ander vertakkings, en gevolglike toename in die inkome van die landboubedryf. ${ }^{3 a}$ ' $n$ Deel van hierdie verhoogde inkome was deur die staat sowel as die ander sektore in die vorm van subsidies en prysskemas gesubsidieer, die regverdigheid waaroor daar verskil van mening bestaan, omdat die surplus gewoonlik teen verlies op die buitelandse mark verkoop moes word.

Nietemin, feit bly dat in die tussen-oorlogse stadium die Suid-Afrikaanse landbouproduksie snel uitgebrei is. Of oor-ontwikkeling en sekere distorsies uit ' $n$ doeltreffendheidsoogpunt plaasgevind het al dan nie, was hierdie ontwikkeling tot selfvoorsiening uit 'n oorlogsoogpunt gewens, en sou daarom gedurende die Tweede Wêreldoorlog voortgesit word, wat 'n uitbreiding in owerheidsbeheer en -inmenging sou meebring. Ten spyte van owerheidshulp het die landbou vooroorlogs nie so vinnig as die reeds genoemde sektore ontwikkel nie, dog die basis gelê was belangrik vir verdere ontwikkeling wat tydens die oorlog en daarna plaasgevind het.

Dit is ' $n$ bekende feit dat die belangrikste struktuurverandering wat die Suid-Afrikaanse ekonomie in hierdie tussenoorlogse stadium ondergaan het die vinnige ontwikkeling van die industriewese en gepaardgaande arbeidverskuiwing van die landbou na industriewese en ander vinniger-ontwikkelende sektore was. Hierdie verskuiwing was veral vinnig oor die tydperk 1936-41 toe die getalle van die blankes in die landbou verminder het teen ' $n$ gemiddelde jaarlikse koers van $1,32 \%$. Terselfdertyd het die industriewese oor dieselfde tydperk 'n toename van $7,49 \%$ ondervind. ${ }^{4}$ Soortgelyke gegewens is ongelukkig nie vir ander volksgroepe beskikbaar nie, maar daar kan aanvaar word dat dieselfde tendens hom hier openbaar het.

Uit die bostaande kort uiteensetting kan afgelei word dat Suid-Afrika minstens die basis gehad het vir 'n gesonde oorlogsekonomie. Die totale bevolking het oor die hele tydperk vanaf Uniewording 1911-36 snel toegeneem, die blanke gedeelte teen $1,8 \%$, die ander volksgroepe teen $2,0 \%$ jaarliks. ${ }^{5}$ Statistiese data toon aan dat in $1936,24,5 \%$ van die blankes by die landbousektor betrokke was teenoor $18,15 \%$ by nywerhede, $16,29 \%$ by handel en finansies, $11,13 \%$ by owerheidsdienste en administrasie, $10,65 \%$ by vervoer, $6,42 \%$ by mynwese en $5,28 \%$ by bouwerk en konstruksie. ${ }^{6}$ Indiensneming streeksgewys toon ook duidelike verskille, naamlik 'n groot mate van landbou-ekonomiese konsentrasie in die OVS, en kommersieel-ekonomiese konsen- 
trasie in Natal, terwyl die Transvaal relatief hoë syfers in mynwese, industrieë en ingenieurswese toon. Kaapland toon nog 'n groot mate van landbou-ekonomiese konsentrasie, hoewel tekens van ontwikkeling in sekere industriële sektore reeds na vore getree het.

Vir doeleindes van analise van die Suid-Afrikaanse oorlogsekonomie moet die vernaamste gebeurtenisse van die oorlog van die kant van die geallieerdes, soos dit Suid-Afrika geraak, het ook steeds as agtergrond in gedagte gehou word.

Met die uitbreek van die oorlog in September 1939 het elke oorlogvoerende land stappe gedoen om sy eie ekonomie te beveilig en dié van die vyand skade te berokken. Duitsland se besetting van Noorweë, Denemarke, Nederland en Frankryk in April en Mei 1940, en Italië se oorlogsverklaring in Junie, het die ekonomiese vooruitsigte van die Statebond direk geraak. Voorradebronne is daardeur afgesny; die Spilmoondhede het vooruitgeskowe basisse verkry vanwaar hulle skepe kon aanval, en die Middellandse See is vir handelsverkeer gesluit.

Die aanname van die Bruikleenwet deur die Verenigde State van Amerika in Maart 1941 het Brittanje en die res van die Statebond in staat gestel om Amerikaanse voorrade sonder onmiddellike betaling te verkry. Ten gevolge van Hitler se inval in Rusland in Junie moes nog meer Geallieerde skepe en voorrade opgeoffer word ten einde noodsaaklike hulp aan die Sowjet-Unie te verskaf. Japan se aanval op Pearl Harbour in Desember 1941 het die Verenigde State in die oorlog teen beide Japan en Duitsland betrek. Dit het veroorsaak dat die Verenigde State se hulpbronne meer as ooit vir sy eie behoeftes nodig was.

In 1942 het die Japannese verowering van die Fillipynse en Oos-Indiese Eilande Maleia en Birma die toevoer van noodsaaklike produkte uit dié lande, veral van rubber, voedsel, olies, wasprodukte en manillahennep, afgesny. Dit was eers lank na die oorlog dat enige sodanige voorrade uit hierdie lande weer in omloop gekom het.

Suid-Afrika was in 'n baie hoë mate van invoere afhanklik. Die toevoer van goedere hierheen is egter geraak deur ' $n$ tekort aan skeepsruimte. Dit is veroorsaak deur die duikbootveldtog en die vereistes van die strydmagte. Eersgenoemde was op sy ernstigste tussen Februarie en Oktober 1942 en in die tweede helfte van 1943.
Laasgenoemde het gewissel volgens die hewigheid van die krygsbedrywighede. 'n Aansienlike aantal skepe was in die woestynveldtog in Noord-Afrika in 1940-1943 betrokke, terwyl buitengewone groot getalle geverg is deur die landings in Noord-Afrika in November 1942, die inval in Frankryk in Junie 1944, en vir die verskeping van dringende krygsvoorrade vir die Amerikaanse leër in Europa teen die einde van dié jaar en die begin van 1945. Die Amerikaanse veldtog in die Stille Oseaan het geweldige laairuimte in beslag geneem. ' $n$ Aansienlike kwota was ook voortdurend betrokke by die vervoer van noodsaaklike voorrade na Brittanje.

Tot die tweede helfte van 1941, dws vir twee jaar na die uitbreek van die oorlog, het Suid-Afrika se ekonomie, ten spyte van sekere tekorte, min verandering ondergaan. Van toe af is die Regering egter deur omstandighede verplig om strenger beheer uit te oefen.

Algemene invoer- en uitvoerbeheer is eers in September 1941 ingestel. Dit is gevolg deur die instelling van beheer oor handelsgoedere. In 1942 het hierdie veranderings 'n uitwerking begin toon, maar dit het tyd en ervaring gekos om hulle doeltreffend te laat werk. Die lewering van voorrade is eers in 1943 finaal georganiseer: in Suid-Afrika deur die stigting van die organisasie van die Direkteur generaal van Voorrade in Februarie; in Amerika ten gevolge van die reorganisasie van die liggame wat buitelandse benodigdhede gehanteer het; en in die algemeen deurdat gekombineerde organisasies van die Geallieerde lande in volle werking getree het.

$\mathrm{Na}$ die geslaagde inval in Frankryk in Junie 1944 het dit duidelik begin word hoe sake sou verloop, en voorbereidings vir die oorgang na naoorlogse toestande kon toe in alle erns begin. ${ }^{7}$

\section{Wetgewing en regulasies}

Wetgewing wat aan die dringende eise van 'n oorlogtoestand moet voldoen, kan nie op die langsame gang van die gebruiklike parlementere prosedure wag nie. regerings wat voor 'n posisie te staan kom waar bestaande wetgewing nie die vereiste bevoegdhede verleen nie, word genoodsaak om tydelike daarsonder op te tree. Dit was die geval met die destydse Unie-regering toe die oorlog uitgebreek het. Die Regering het gevolglik daartoe oorgegaan om wette te maak by wyse van proklamasie, ' $n$ vorm van wetgewing wat statutêre bekragtiging vereis. 
Die eerste maatreël was Proklamasie No 201 van 14 September 1939, wat die Landsnoodtoestand-regulasies uitgevaardig het. Hierdie regulasies is vooraf opgestel in afwagting van die noodtoestand. Dit het gehandel oor 'n menigte sake, naamlik van die stigting van die Raad van beheer oor Landsvoorrade, wat met die toepassing van die regulasies oor voorrade belas is, tot sake soos handel met die vyand, die opgaring van goedere, woekerwins en die bewaring van die vrede. Latere proklamasies het die totaal op 37 te staan gebring.

Vroeg in 1940 is hierdie proklamasies geldig gemaak, deur die Wet op Oorlogsmaatreëls, 1940 (Wet No 13 van 8 April 1940). Hierna het die Regering noodmaatreëls gepubliseer, deur spesifieke proklamasies en in sommige gevalle deur Goewermentskennisgewings. Wet No 13 van 1940 het egter geen voorsiening gemaak vir toekomstige optrede van ' $n$ soortgelyke aard nie. 'n Wysigende maatreël, die OorlogsmaatreëlWysigingswet, 1940 (Wet No 32 van 17 September 1940), het aan die Goewerneur-generaal die bevoegdheid verleen om sodanige regulasies uit te vaardig as wat hy vir die doelstellings in die vorige Wet vermeld, nodig geag het.

Die proklamasies en goewermentskennisgewings wat in die tydperk tussen die aanname van die twee wette uitgevaardig is, is van terugwerkende krag gemaak deur hulle by die Bylae van Wet No 13 van 1940 te voeg. Hierna het die Regering noodmaatreëls geproklameer onder die afsonderlike benaming Oorlogsmaatreëls. Die eerste hiervan is op 11 November 1940 uitgevaardig. Vir noodwetgewing insake finansies, sien afdeling oor finansies.

In Mei 1945, onmiddellik na die beëindiging van die oorlog in Europa, is 'n komitee deur die Eerste Minister in die lewe geroep met die doel om alle maatreëls wat nie langer noodsaaklik was nie, te herroep of te wysig, veral dié wat beperkings of ekstra laste of pligte op die publiek gelê het. ${ }^{8}$ Daarna is alle oorlogsmaatreëls ò herroep of in selfstandige wetgewing opgeneem.

\section{Oorlogsproduksie}

Vir die handhawing van ' $n$ totale oorlogspoging is die produksie en lewering van krygstuig en essensiële behoeftes aan die aktiewe magte van kardinale belang. Tot watter mate Suid-Afrika in hierdie behoeftes voorsien het, word vervolgens beskryf. Dit bly egter ' $n$ feit dat die Suid-Afrikaanse produksieprestasies sowel as die oorlogspoging (waarskynlik) nie die maksimum was nie, omdat 'n groot gedeelte van die bevolking nie alleen teen deelname aan die oorlog gekant was nie, maar dit dikwels ook aktief teengestaan het. Tot watter mate dit wel ' $n$ invloed gehad het, kan nie in kort bereken word nie.

Gedurende die vyf jaar voor die uitbreek van die oorlog was dit die beleid en strewe van die Regering om ' $n$ hoër graad van selfvoorsiening te bereik. Die oprigting van Yskor, die uitbreiding van die kragvoorsieningsmaatskappy, die uitbreiding van die goudmynnywerheid met sy beleid om sy bestellings vir ingenieurswerk by plaaslike firmas te plaas, was almal ontwikkelings wat tot die kragtige en bloeiende industrialisasie van Suid-Afrika bygedra het. Alhoewel die Nywerheidsontwikkelingskorporasie eers na die uitbreek van die oorlog in die lewe geroep is, was sy instelling reeds in vredestyd die onderwerp van onderhandelings met die doel om aan nywerhede waarvan die onmiddellike vooruitsigte op wins nie sterk genoeg was om beleggers te trek nie, hulp te verleen sodat hulle in staat gestel kon word om met werksaamhede te begin. Die groot prestasies van die ingenieursnywerheid met die produksie van oorlogsmateriaal sou sonder die vooroorlogstydse periode van uitbreiding en beplanning onmoontlik gewees het. Groot hoeveelhede masjiengereedskap wat bestel is en in die loop van die eerste oorlogsjare afgelewe is, kon dadelik by die masjinerie vir oorlogsproduksie ingeskakel word; die groeiende gees van selfvertroue en die toenemende optimisme het die land in staat gestel om aan onverwagte eise vir nuwe en 'n aansienlik groter produksie te voldoen.

Die Departement van Verdediging het ook sy aandeel tot die algemene beleid van selfvoorsiening bygedra. Die Minister het in 1934 en weer in 1936 aangekondig dat slegs voorrade wat nie binnelands vervaardig kon word nie, aangekoop sou word. In 1933 is 'n sesjaarprogram aanvaar en die Verdedigingsbegroting is tot R12 miljoen verhoog; die plaaslike produksie van oorlogsvoorrade is deur die program sterk aangespoor.

Die vooroorlogse Oorlogsbehoeftesraad is in 1937 ingestel en het op drie verskillende maniere te werk gegaan om ' $n$ 'oorlogspotensiaal' vir die produksie van oorlogsvoorrade te skep. Eerstens is eksperimentele bestellings sonder uitsoek geplaas met die doel om die graad van 
kontrole en akkuraatheid in verskillende werkswinkels te toets; tweedens is klein eksperimentele bestellings vir goedere wat op ' $n$ herhalingsgrondslag vervaardig kon word, sonder inagneming van onkoste geplaas, en derdens is bestellings vir ' $n$ aansienlike hoeveelheid goedere geplaas met 'n kort afleweringstermyn met die oog op 'n moontlike vermindering van produksiekoste. Alhoewel die Oorlogsbehoeftesraad nie lank bestaan het nie, het hy nietemin vasgestel dat daar 'n taamlike groot plaaslike kapasiteit vir die vervaardiging van oorlogsvoorrade was, dat daar ' $n$ groter kapasiteit vir die vervaardiging van masjiengereedskap bestaan het as wat verwag is, en dat in die geval van baie werkwinkels die dae van loswerk verby was en dat hulle reeds vir gespesialiseerde produksie georganiseer was.

Gedurende hierdie jare is baie besprekings gevoer oor die vraag of krygsvoorradefabrieke met die hulp van Regeringsbestellings opgebou moes word en of die Staat sy eie fabrieke vir die vervaardiging van krygsmateriaal moes oprig. Die enigste uitslag van die besprekings was egter dat daar in 1938 die Staatsammunisiefabriek by die Munt ingestel is.

Ook nog voor die uitbreek van die oorlog is daar ' $n$ ad hoc-komitee in die Departement van Handel en Nywerheid ingestel met die opdrag om 'n nasionale register van sleutelmanne op te stel en om maatreëls te tref vir die beheer van die gebruik van die land se hulpbronne in die geval van oorlog en om inflasie en onwettige opgaring te voorkom. ${ }^{9}$

\section{Die uitbreek van die oorlog in 1939}

Die Landsnoodtoestandregulasies wat op 14 September afgekondig is, het die raad van $\mathrm{Be}$ heer oor Landsvoorrade in die lewe geroep. Benewens ander pligte het die Raad die verantwoordelikheid aanvaar om die besigheids- en finansiële aspekte van die bestellings vir die Verdedigingsmagte waar te neem. Wat hoeveelhede en die spesifikasies vir militêre toerusting betref, was dit die taak van òf die Direkteur-generaal van Tegniese Dienste of van die Kwartiermeester-generaal om daarvoor te sorg. Die Raad van Beheer oor Landsvoorrade is ook as die plaasvervanger van die vooroorlogse Oorlogsbehoeftesraad beskou. Die Minister van Verdediging het ook ' $n$ Tegniese Adviserende Komitee in die lewe geroep om advies in verband met militêre bevoorrading te gee. Die komitee het aanbeveel dat ' $n$ spesiale direktoraat vir die verkryging of vervaardiging, geskep en onder 'n siviele sakebestuurder geplaas moes word.

\section{Oorlogsvoorrade vooraf}

Dit is duidelik dat die voorrade-toestand van die Unie Verdedigingsmag (UVM) in 1939 haglik was, en die pogings van die Direktoraat van Oorlogvoorrade om plaaslike vervaardiging te bevorder, nog maar in ' $n$ eksperimentele stadium was. Dit word bewys deur die volgende syfers van die voorrade-toestand van die UVM in September 1939: 2 tenks; 2 pantserkarre; $28 \times$ 3" mortiere; 1893 pistole, 65000 gewere; 500 handgranate; 1820 masjiengewere; 20 tenkafweergewere; $6 \times 2$ pdr tenkafweerkanonne; $8 \times$ 3" Lugafweerkanonne; $4 \times 3,7$ " Howitzers, $4 \times 6$ " Howitzers; $4 \times 60$ pdr kanonne, $4 \times 6$ " kanonne.

Daar was beperkte hoeveelhede ammunisie vir hierdie wapens vir ' $n$ kort tyd van opleiding beskikbaar. Die Lugmag het nie genoeg vliegtuie gehad om eers 2 eskaders vir operasionele doeleindes te vorm nie, en die Vloot het net oor een mynveër beskik. ${ }^{10}$

\section{Direkteur-generaal van Oorlogsbehoeftes (DGWS)}

Die Direkteur-generaal van Oorlogbehoeftes se organisasie is dus ingestel ten voordeel van die Departement van Verdediging met die opdrag om die aankoop of vervaardiging van goedere vir die Departement òf plaaslik òf oorsee te reël en toe te sien dat die ander regeringsdepartement betaling ontvang vir die dienste wat hulle aan die Departement van Verdediging gelewer het. Die Direkteur-generaal van Oorlogsbehoeftes het nie hierdie bedrywighede outomaties oorgeneem of hulle enigsins onder sy beheer gestel nie. Tog het hy geleidelik die werk in verband met afrekening en die aankoop van baie goedere en dienste wat deur ander departemente aan die Departement van Verdediging gelewer is, oorgeneem en die rekenings deur die rekenmeester, dws die Sekretaris vir Verdediging, aan die Verdedigingsmagtigingskomitee ter vereffening voorgelê.

Die Hoofkwartier van die nuwe organisasie was in Pretoria gehuisves om naby die Verdedigingshoofkwartier en die Minister van Verdediging te wees. 
Kragtens Landsnoodtoestandregulasie No 31 is aan die DGWS omvattende bevoegdheid verleen om aankope te doen of om kontrakte te sluit vir die produksie van goedere wat deur die Departement van Verdediging vir die doeltreffende voortsetting van die oorlog nodig was. Hy was nie verplig om die goedkeuring van die Tenderraad te verkry nie. Hy is gemagtig om inligting in verband met die bestaande voorrade en vervaardigingskapasiteit in te win en ook om inspeksie te doen. Verder is hy volmag gegee om grond of goedere te kommandeer en om die vervaardiging van bepaalde artikels in bepaalde hoeveelhede af te dwing; tot op daardie tydstip is hierdie bevoegdheid kragtens Landsnoodtoestandregulasies Nos 6 en 7 slegs aan Ministers van die Staat verleen.

Gedurende die tydperk Desember 1939 - Mei 1940 het die administratiewe komitee van die nuwe organisasie, bekend as die Bestuurkomitee, dikwels in Pretoria vergadering gehou en gespesialiseerde komitees ingestel wat die produksie van krygstuig, militêre stewels en tekstielware vir die leër, en ook prysbeheer behartig het. ' $n$ Tweede en bedrywiger hoofkwartier het tegelykertyd in Johannesburg ontstaan waar die DGWS, die Adjunk DGWS en die produksiesentrums vir krygsbehoeftes en ' $Q$ '-behoeftes hoofsaaklik gevestig was. Die hoofkwartier in Johannesburg het te koste van die Pretoriase hoofkwartier gegroei, en in Oktober 1941 het slegs 'm onbeduidende plaaslike kantoor in Pretoria oorgebly. ${ }^{11}$

\section{Skakels met die Departement van Verdediging en die Generale Staf}

Om die Direkteur-generaal van Oorlogsbehoeftes by te staan, het die Minister van Verdediging ' $n$ Direktoraat vir Oorlogsbehoeftes aangestel; drie van sy lede was lede van die nuwe organisasie, nl die Direkteur-generaal van Oorlogsbehoeftes self, sy Adjunk-direkteur-generaal en sy Tegniese Direkteur. Die ander drie lede was die Sekretaris van verdediging, die Voorsitter van die Unieraad vir Tenders en Leweransies en die Voorsitter van die Raad van Beheer oor Landsvoorrade. Nog 'n direkteur is kort daana bygevoeg, $\mathrm{nl}$ die voormalige kwartiermeestergeneraal vand ie Departement van Verdediging; hy is na die nuwe organisasie gesekondeer en was ' $n$ belangrike skakel ten opsigte van die Departement van Verdediging se vereistes.

Die Direktoraat vir Oorlogsbehoeftes het goeie werk verrig maar dit het slegs ' $n$ kort tydjie bestaan aangesien die Direkteur-generaal van Oorlogsbehoeftes geleidelik die werk wat deur die lede van die Direktoraat die Oorlogsbehoeftes gedoen is, oorgeneem het. Na Januarie 1940 het die Direktoraat nie meer vergader nie. Tog is daar met die twee-weeklikste verslae, voortgegaan aangesien dit nuttige rapporte gelewer het oor die werk wat deur die organisasie verrig is.

Aangesien dit vir die Direkteur-generaal van Oorlogsbehoeftes dringend nodig was om met Verdediging in noue aanraking te bly, is daar in Maart 1940 aan hierdie behoefte voldoen deur die Oorlogsbehoeftesraad in te stel Hierdie Raad is in November 1940 deur die Oorlogskomitee vervang wat onder die voorsitterskap van die Minister van Verdediging ingestel is. Die oorlogskomitee het twee-weekliks byeengekom en al was dit die voorneme dat die werk van die komitee van groter omvang as dié van sy voorganger moes wees, het ' $n$ groot gedeelte daarvan tog binne dieselfde gebied geval.

\section{Reorganisasie van die Direkteur-generaal van Oorlogsbehoeftes se werk in 1940}

Die rampspoedige gebeurtenisse van Mei 1940 het gou meegebring dat nuwe pligte aan die organisasie van die Direkteur-generaal van Oorlogsbehoeftes opgelê is wat sy aard verander het en teweeggebring het dat sy dienste aan die Unie-verdedigingsmag slegs ' $n$ gedeelte van sy bydrae tot die oorlogspoging uitgemaak het. Dit het reeds voor Mei 1940 duidelik geword dat die Verenigde Koninkryk maar min goedere vir verkoping aan die Unie oorgehad het, terwyl die Verenigde State van Amerika as gevolg van sy neutraliteitswetgewing slegs verouderende krygstuig kon verkoop. Plaaslike produksie het dus al hoe belangriker geword.

Oorlogsvoorrade is in twee hoofkategorieë ingedeel. Die een groep, naamlik ' $Q$ ' - of ' $C$ '-items, het al die benodigdhede van die leër ingesluit wat deur sowel burgerlike as militêre personeel gebruik kon word, soos bv persoonlike uitrusting, stewels, klere, komberse, kampe, hospitale en hospitaaltoerusting, ens. Die nywerhede wat reeds bestaan het, het ' $n$ merkwaardige oorlogspotensiaal gehad, en vroeg in die oorlog is die beleid aanvaar dat die Direkteur-generaal van Oorlogsbehoeftes op 30 persent van die produksie van firmas wat sodanig goedere vervaardig het, aanspraak kon maak. Bowendien kon hy betrokke nywerhede deur grootskaalse bestel- 
lings heelwat laat uitbrei. Die ander groep, naamlik ' $T$ '-items, het daarenteen uit die tegniese toerusting van 'n oorlogvoerende nasie bestaan wat normaalweg massaproduksiemetodes en 'n hoë mate van verwisselbaarheid vereis het; hierdie items kon oor die algemeen nie op ander gebiede gebruik word nie nadat daar in die behoeftes van die oorlog voorsien is.

Die vooroorlogse Oorlogsbehoeftesraad het reeds in vredestyd ' $n$ aansienlike oorlogspotensiaal vir 'n groot aantal items soos staalhelms, handgranate, mortiere en mortierbomme, springstowwe en kleingeweerammunisie ontdek en dit aangemoedig. As gevolg van die instelling van die organisasie van die DGWS en die bestellings van nie alleen die Unieverdedigingsmag maar ook die Britse Voorrade Ministerie het die produksie van genoemde items spoedig ' $n$ hoë peil bereik. Die ontwikkeling van 'T'-produksie het egter probleme meegebring wat heelwat van dié in verband met ' $Q$ '-items verskil het. Waar ' $T$ 'items betrokke was, was die enigste afnemer die militêre owerheid. Bowendien moes militêre spesifikasies tov sowel die ontwerp as die materiaal noukeuring gevolg word.

Die Munisieproduksiekomitee onder die AdjunkDGWS (Tegnies) het nou die belangrikste administratiewe uitvoerende komitee van die organisasie geword. Hierdie Komitee is aanvanklik aangestel met die opdrag om die vervaardiging van geskut by Cofac (Central Ordnance Factory), die sentrale krygsbehoeftesfabriek, wat in 1940 deur die DGWS opgerig is, waar te neem maar byna onmiddellik is sy opdrag uitgebrei en moes hy die DGWS raadgewend bystaan en in alle sake betreffende die verkryging of vervaardiging van krygsbehoeftes ten behoewe van die DGWS handelend optree. Daar is veertien onderkomitees aangestel om die vervaardiging van geskut, ammunisie, pantserkarre, springstowwe, ens, te behartig; hierdie komitees het op hul beurt aan die Munisieproduksiekomitee verslag gedoen. Die Munisieproduksiekomitee het planne vir tegniese werk gereël, wat deur die oorlogsbehoeftesorganisasie gekontroleer moes word, en het die werk aan firmas uitgegee wat die beste daartoe in staat was om dit te behartig.

Wat beleidsake betref, het die Munisieproduksiekomitee onder die Direkteur-generaal van Oorlogsbehoeftes, ook onder sekere komitees soos die Oorlogsbehoefteskomitee en die Oorlogskomitee gestaan, maar sy advies oor tegniese aangeleenthede het die grootste gesag gedra, en die Munisieproduksiekomitee het in- derdaad in 'n groot mate die Bestuurskomitee van die DGWS vervang wat in onbruik geraak het. $^{12}$

\section{Oorlogsproduksie en samewerking met geallieerdes}

SA se vredestydse beplanning tov oorlogsvoorrade is net soos dié van die ander dominiums, sonder enige koördinasie met die VK onderneem. Gedurende die eerste maande van die oorlog was produksie in SA slegs gemik op bevoorrading van die UVM. Met verloop van die oorlog het die vraag egter ontstaan of ' $n$ gedeelte van die nuwe vervaardigingskapasiteit van die VK nie in SA opgerig kan word nie. Aanvanklik was Britse adviseurs daarteen gekant hoofsaaklik weens die tyd- en afstandprobleem, hoewel al sie grondstowwe beskikbaar was. Die Britse owerheid het egter vroeg bevestig dat hulle bereid sal wees om alle surplusoorlogsgoedere op te neem en aansoeke vir besondere toerusting te oorweeg. Die eerste praktiese resultaat hiervan was die verskaffing van toerusting vir die vervaardiging van kleingeweerammunisie. ${ }^{13}$ Hierdie samewerking sou daarna baie verder uitgebou word.

\section{Die Voorsieningsraad van die Oostelike Groep}

Die veranderings in die omvang van die Direkteur-generaal van Oorlogsbehoeftes se organisasie is ' $n$ verdere stoot gegee deur die instelling van die Voorsieningsraad van die Oostelike Groep. Die Konferensie wat in Oktober 1940 in Indië byeengeroep is, is deur afgevaardigdes uit Suid-Afrika, Australië, Nieu-Seeland, Indië, Birma, Maleia, Hong-Kong, Ceylon, Sjanghai, Noord- en Suid-Rhodesië, die Brits-Oos-Afrikaanse gebiede en Palestina bygewoon. Die Britse Voorradeministerie is by die konferensie deur die Roger-sending verteenwoordig, wat Suid-Afrika op pad na die konferensie en weereens met sy terugkeer besoek het. Die konferensie het die Voorsieningsraad van die Oostelike Groep ingestel met die doel om permanente masjinerie vir regstreekse skakeling en besprekings tussen die verskillende lande van die groep te skep. Die ideaal waarna gestreef is, was dat die Oostelike Groep een groot onafhanklike eenheid moes uitmaak waarvan elke lid sy produksieplanne met dié van die ander lede in ooreenstemming moes bring. Die produksiesurplus wat oorgebly het nadat daar in die be- 
hoeftes van al die ledelande van die hele Oostelike Groep voorsien is, kon daarna aan die Verenigde Koninkryk beskikbaar gestel word wat dit broodnodig gehad het.

Die militêre skakel tussen die Unie en die Sentrale Voorsieningskantoor in Indië (Central Provision Office) dws die uitvoerende organisasie van die Voorsieningsraad van die Oostelike Groep, was die Kwartiermeester-generaal, bekend in dié hoedanigheid as die Suid-Afrikaanse Voorsieningsoffisier, terwyl die burgerlike voorsieningsorganisasie wat ooreengestem het met die wat in die ander lande van die Oostelike Groep ingestel is, die organisasie van die Direkteur-generaal van Oorlogsbehoeftes was.

Japan se toetrede tot die oorlog in Desember 1941 het ' $n$ merkwaardige uitwerking op die organisasie van die Oostelike Groep gehad. Nederlands-Oos-Indië het 'n lid geword, maar die gebied Sjanghai, Maleia en Hong-Kong is van die Oostelike Groep afgesny. Die bedreiging van Australië, Nieu-Seeland en Indië het ten gevolge gehad dat ' $n$ groot gedeelte van hul produksie vir die verdediging van hul eie land en vir die behoeftes van die VSA gereserveer moes word. Gedurende 1942 was die Voorsieningsraad van die Oostelike Groep dus hoofsaaklik van twee van sy lede afhanklik, nl Indië en Suid-Afrika. In 1943 het daar ' $n$ reorganisasie plaasgevind as gevolg waarvan hierdie raad toe 'n deel van die Gesamentlike Beplanningsraad (Joint Planning Council) van die Verenigde Koninkryk (VK) en die Verenigde State van Amerika (VSA) geword het, wat die gesamentlike pogings verder moes koördineer. ${ }^{14}$

\section{Bruikleen}

a. Die eerste groot verandering in buitelandse verkryging is deur die aanname van die Amerikaanse Bruikleenwet (Lend Lease Act) op 11 Maart 1941 teweeggebring. Die hoofdoel van hierdie Wet was om die Verenigde Koninkryk in staat te stel om sonder onmiddellike betaling sy benodigde voorrade uit die Verenigde State te verkry, maar die voordele daarvan is nie tot Groot-Brittanje beperk nie en is met verloop van tyd tot nagenoeg veertig lande uitgebrei. Dit het egter ook die uitwerking gehad om die aard en omvang van die voorrade wat uit die VSA verkrygbaar was, te reël. Die Bruikleenwet het die President die bevoegdheid verleen om 'verdedigingsartikels' (defence articles) aan enige land te verskaf wie se verdediging hy as lewensbelangrik vir die verdediging van die Verenigde State beskou het, en wel teen betaling of terugbetaling in natura of leenvergoeding by wyse van die een of ander regstreekse of onregstreekse voordeel wat hy as bevredigend geag het. Die begrip 'verdedigingsartikel' is so wyd moontlik vertolk en het uiteindelik 'n groot reeks nie-militêre goedere gedek wat vir die voortsetting van die stryd noodsaaklik was met inbegrip van grondstowwe en gedeeltelik verwerkte materiale soos staal, masjinerie vir die produksie van wapens en essensiële goedere, skepe en die dienste van diegene wat hulle beman het, voedsel, en selfs tabak wat ononbeerlik vir die handhawing van die moreel van die strydmagte en die burgerlike industriële bevolking was. Al hierdie voorrade is sonder enige onmiddellik quid pro quo gelewer.

b. Die Bruikleenadministrasie, bekend as Olla (Office of Land-Lease Administration), het sy eie strenge standaarde ten opsigte van noodsaaklikheid opgestel en het by verre na nie al die noodsaaklikheidsertifikate wat deur die SA-owerhede, uitgereik is, aangeneem nie. Aansoeke kon of vir bruikleen aangeneem word, ò vir verkryging onder die bruikleenprosedure teen kontantbetaling goedgekeur word (bruikleen terugbetaalbaar in kontant), ò afgekeur word. In laasgenoemde geval moes die betrokke goedere, indien dit verkrygbaar was, in die vrye handel aangekoop word. Daar was egter byna geen vrye handel nie aangesien regeringsbestellings en bestellings wat deur die Regering goedgekeur is, feitlik al die verkrygbare materiale en vervaardigingsfasiliteite geabsorbeer het.

c. Alle twyfel in verband met die vraag of voorrade regstreeks aan $\mathrm{SA}$ toegestaan kon word of deur die Verenigde Koninkryk verkry moes word, is op 15 November 1941 uit die weg geruim toe die President uitdruklik verklaar het dat Suid-Afrika ook vir bruikleenhulp in aanmerking kon kom. ${ }^{15}$

As gevolg van die aanvanklike neutraliteit van die VSA moes alle aankope daar in kontant geskied, wat spoedig onmoontlik geword het vanweë die oorlogverpligtinge in geallieerde lande. Die bruikleenstelsel is dus daargestel om bondgenote te help om die vrye wêreld te verdedig sonder dat finansiële oorwegings hulle pogings aan bande sou lê. Om die SA-aankope uit die VSA met VK-behoeftes te koördineer is die SA 
aankoopskommissie in New York (later Washington) gestig. Waar SA aanvanklik na eie keuse op ' $n$ kontantbasis in die VSA bly koop het, is hul tog later agv groter mededinging en aanvraag verplig om die voorwaardes vir bruikleen te aanvaar, waardeur alle aankope gesentraliseer moes word en 'n stelsel van invoerlisensiëring en -beheer toegepas moes word. ${ }^{16}$ Die Suid-Afrikaanse behoeftes deur DGWS en die Spoorweë is direk via hierdie liggaam bekom, terwyl alle ander staatsdepartement hul behoeftes via die Dept Handel en Nywerheid moes kanaliseer. ${ }^{17}$ Die SA oorlogsbehoeftes kon in die algemeen geredelik onder die bruikleenstelsel verkry word, dog probleme het ontstaan waar dringende behoeftes byvoorbeeld vir Yskor en die myne verkry moes word en direkte essensialiteit moeiliker bewysbaar was. ${ }^{18}$ Die afhandling van hierdie transaksies word onder finansies bespreek.

\section{Buitelandse verkryging}

Hoewel nie altyd van almal gebruik gemaak is nie, moes Suid-Afrika as deel van die VK vir oorlogsbehoeftes deur die volgende organisasies werk:

a. British Supply Council. Die Sentrale Britse organisasie vir die verkryging van voorrade en dienste in die VSA;

b. Office of Lend Lease Administration. Die reedsgenoemde Amerikaanse liggaam met mag oor alle bruikleentransaksies;

c. Army and Navy Munitions Board and Joint Aircraft Committee. Amerikaanse organisasies wat prioritiet moes bepaal en toesien dat die dringendste behoeftes bevredig word.

d. War Production Board. Die Amerikaanse produksie-organisasie vanaf 1942 in algehele beheer van oorlogsproduksie en -verkrygingsprogramme;

e. Combined Munitions Assignment Board. Die sentrale poelorgaan wat ook oor die toewysing van strategiese behoeftes geadviseer het.

f. Combined Raw Materials Board. Gesamentlike liggaam wat die mees doelmatige benutting van die gekombineerde grondstofbronne moes beheer;

g. War Shipping Administration and Combined Shipping Adjustment Board, wat onderskeidelik skeepsprogramme gekoördineer het en as poelorganisasie vir skeepsruimte ageer het. ${ }^{19}$

\section{Oorlogsvoorrade: verkryging en produksie}

Die organisasie vn die DGWS het ' $n$ tweeledige doel gehad, $\mathrm{nl}$

a. om krygsmateriaal en oorlogsvoorrade wat nie plaaslik vervaardig kon word nie, in die buiteland aan te koop, en

b. om al die fasiliteite in SA vir die plaaslike produksie van oorlogsvoorrade tot die uiterste te organiseer. Sekere soorte klaargemaakte oorlogsmateriaal is deur die 'War Office' verskaf in hoeveelhede wat in die oorlogsgebiede, selfs waar die stryd hewig was, ontbeer kon word. Die betrokke krygsvoorrade het hoofsaaklik uit die soorte bestaan wat vir die opleiding van Suid-Afrikaanse divisies nodig was; hierdie divisies, wat SA onderneem het om na oorlogstonele te stuur, het hul opleiding grotendeels onmiddellik agter die gevegslinie en nie in SA self ontvang nie. $\mathrm{Na}$ die toetrede van die Verenigde State van Amerika tot die oorlog is sodanige oorlogsvoorrade deur die Londense Munisietoekenningsraad (Munitions Assignment Board) toegewys; hierdie Raad was self 'n gedeelte van die Gesamentlike Munisietoekenningsraad (Combined Munitions Assignment Board). Militêre verteenwoordigers van Suid-Afrika het die vergaderings van die Munisietoekenningsraad bygewoon met die doel om die toekenning van sodanige voorrade te bepleit.

Weens vertraging wat deur die skaarste aan materiaal oorsee of deur die tekort aan skeepsruimte veroorsaak is, het die DGWS die produksie van sekere soorte oorlogstuig vir die UVM en later ook vir die gebruik van geallieerde regerings onderneem.

Hieronder volg besonderhede van sommige van die vernaamste items wat verskaf is:

a. Geskut. Die vervaardiging van die 3.7" Howitser is reeds onder die vooroorlogse Oorlogsbehoeftesraad aangepak. Dit was die hoofrede waarom die Direkteur-generaal van Oorlogsbehoeftesraad die program van die produksie van gemeganiseerde eenblokhowitzers onderneem het. Hulle is by Cofac vervaardig en teen die einde van 1941 is 166 van hulle voltooi. ' $n$ Verdere dertig is vervaardig en die meeste hiervan is na Indië gestuur waar hulle in die Birmaveldtog gebruik is. Daarna is 300 sesponder-tenkafweerkanonne op bestelling van die VK gemaak, en in 
1944 is 'n program vir die produksie van 3.7" pakhowitzers vir gebruik in die Verre Ooste aanvaar en ' $n$ honderd van hulle is voltooi. In die werkwinkels van die Crown Mines is ' $n$ honderd tweeponder-tenkafweerkanonne gemaak wat op Suid-Afrikaanse pantserwaens gemonteer is. Die waarde van die geskutprogram het R6m oorskrei. Geweerlope en geweeronderdele is ook in groot hoeveelheid gemaak as deel van die onderdele- en herstelwerkprogram wat later beskryf word.

b. Ammunisie. Die vooroorlogse ammunisieinstallasies by die Munt is grootliks uitgebrei om setmate en ykinstumente vir ander afdelings van die organisasie van die DGWS te vervaardig, asook vir die Munt se eie ammunisie-installasies in Pretoria en Kimberley wat ook aansieklik uitgebrei is. Verder is daar baie tipes ammunisie gemaak waarvan die grootste gedeelte uit 800 miljoen patrone vir kleingeweers bestaan her wat teen ' $n$ koste van meer as R13m geproduseer is. Agtienponder- sesponder-tenkafweerkanon-, tweeponder-tenkafweerkanon- en 3.7" howitzerammunisie is ook in groot hoeveelhede vervaardig.

c. Granate. Die granaatdoppe is deur Stewarts $\&$ Lloyds vervaardig en ' $n$ baie nuttige program is te Ladysmith aangepak om die doppe van 25-ponder granate wat afgevuur en op die slagvelde van die Midde-Ooste opgetel is, te herstel en weer te laai.

d. Bomme. Lugbomme van 250 pond, 500 pond en 1000 pond is deur die SA Spoorweë, Scaw Alloys, Durban Falkirk, die Crown Mines, die Witwatersrand Gold Mining Company en Yskor vervaardig. Die springladings hiervoor is deur die firma African Explosives and Chemical Industries in sy verskillende springstoffabrieke geproduseer. Granate en bomme ten bedrae van meer as R50 miljoen is gemaak. ' $n$ Totaal van 600,000 volledige lugbomme en meer as drie miljoen lugoefenbomme is vervaardig. mortierbomme is deur Millers' Inventions, Dunswart en deur Barratt \& Pillans geproduseer.

e. Infanteriemortiere. Die vooroorlogse program vir die vervaardiging van 11,000 volledige infanteriemortiere, 16,000 mortierrigmiddels en 3,000 mortierafuitstande is spoedig uitgebrei en voorsienign is gemaak vir grootskaalse produksie deur die Suid-Afri- kaanse Spoorwegwerkwinkels en private firmas. Die geldwaarde van die program het R2 miljoen oorskrei. Daar is ook 500,000 landmyne en vyf miljoen handgranate gemaak, en die produksie, wat op vooroorlogse ondervinding gebaseer is, het vinnig gevorder.

f. Pantserkarre. Bakke vir pantserkarre op ingevoerde onderstelle is deur Consolidated Engineering Industries vervaardig. Verskillende tipes is gemaak, en die finale getal bakke wat geproduseer is, het nagenoeg 6,000 bereik met ' $n$ geldwaarde van meer as R8 miljoen. Die karre is in Abessinië en in die Midde-Ooste gebruik

g. Belman-vliegtuigloodse. 'n Groot aantal staalloodse en Callender Hamiltonbrûe is vir gebruik in die Unie en vir uitvoer na die lande van die Oostelike Groep deur dieselfde firmas vervaardig.

h. Sein- en Radiotoestelle. ' $n$ Program vir die produksie van hierdie uitrusting is op geslaagde wyse deur Sidney Clow en Phillips Denbigh uitgevoer. Die waarde daarvan was oor die R4 miljoen.

j. Herstelwerk en onderdele. Herstelwerk en die produksie van onderdele was 'n waardevolle bydrae tot die geallieerde oorlogspoging aangesien dit minder tyd in beslag geneem het om herstelwerk aan vliegtuie en geskut te doen en ook doeltreffender was as om nuwe vliegtuie en nuwe kanonne te vervaardig. Dit was ' $n$ program wat die werkwinkels vir loswerk in Suid-Afrika goed gepas het, en na monsters uit die Midde-Ooste per vliegtuig na die Unie gebring is, is baie duisende onderdele gemaak en binne 'n kort tydjie langs dieselfde weg afgelewer. Dit was hierdie program wat vir Suid-Afrika die naam van die Midde-Ooste se basiswerkplaas verdien het. In hierdie verband moet melding ook gemaak word van die uitgebreide program van skeepsherstelwerk wat by alle kushawens onderneem is. Die grootste gedeelte van hierdie tegniese produksie van die Direkteur-generaal van Oorlogsbehoeftes is in fabrieke vervaardig wat vir spesifieke doeleindes opgerig is, of in anneksfabrieke wat uitsluitlik deur die Direkteur-generaal gefinansier en beheer is maar wat aan reeds bestaande ingenieurswerkwinkels verbonde was. Dit het ook noue samewerking met die Britse Voorradeministerie betreffende teg- 


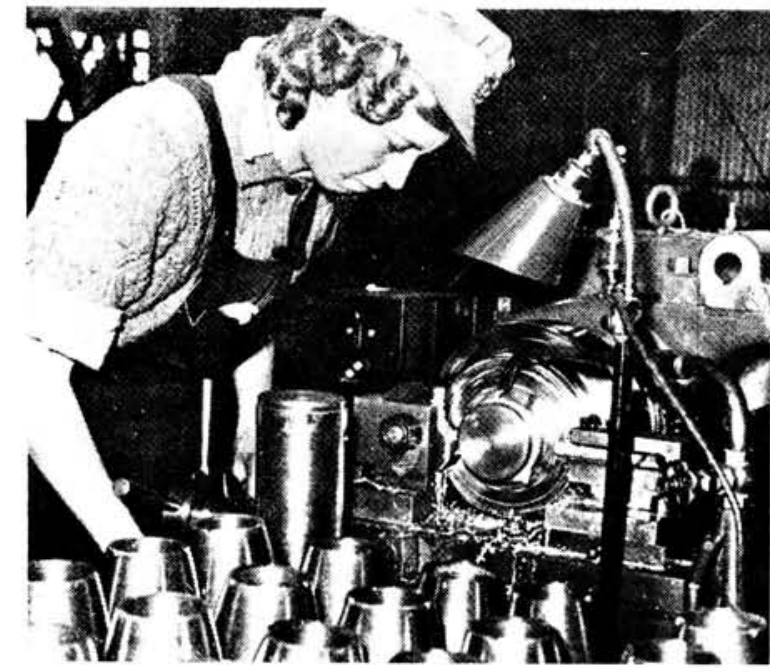

Oorlogsvoorrade: Kanonkoeëls vir die 3.7 Howitzers word deur 'n vrou in 'n Suid-Afrikaanse fabriek

vervaardig

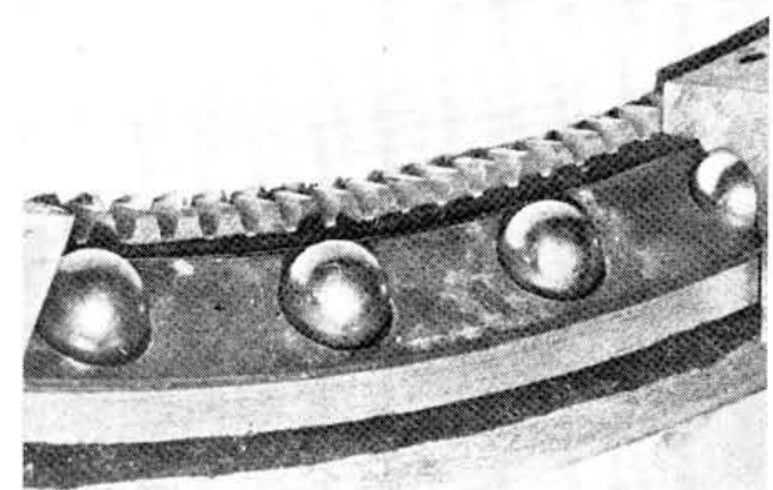

Vervaardiging van koeëllaars vir die skiet-toring van 'n pantservoertuig, WO2

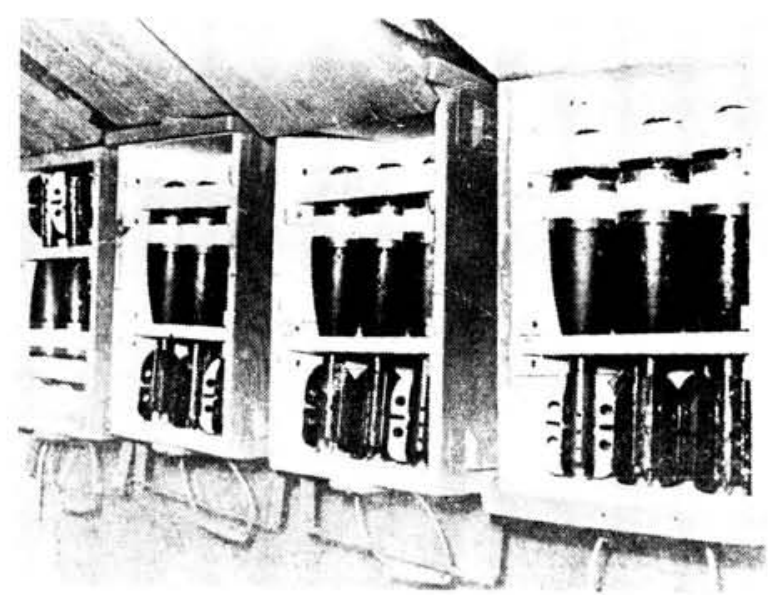

Oorlogsvoorrade: vervaardiging van $3^{\prime \prime}$ kaliber mortierbomme in 'n Suid-Afrikaanse fabriek

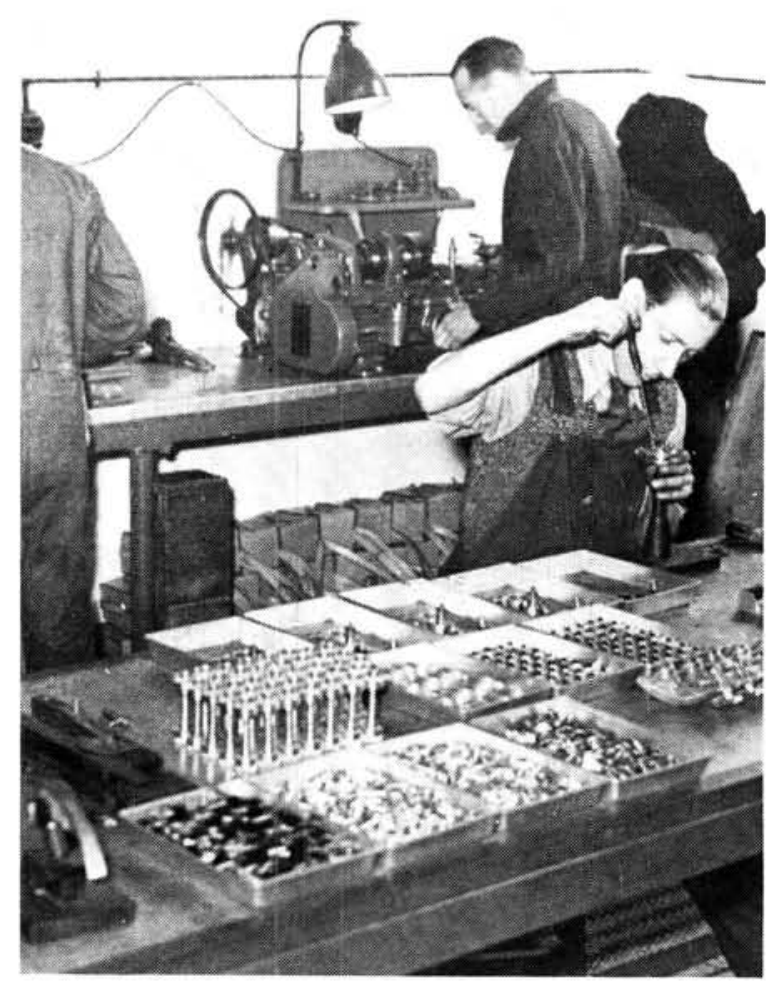

Vervaardiging van mortiervisiere in 'n Suid-Afrikaanse fabriek

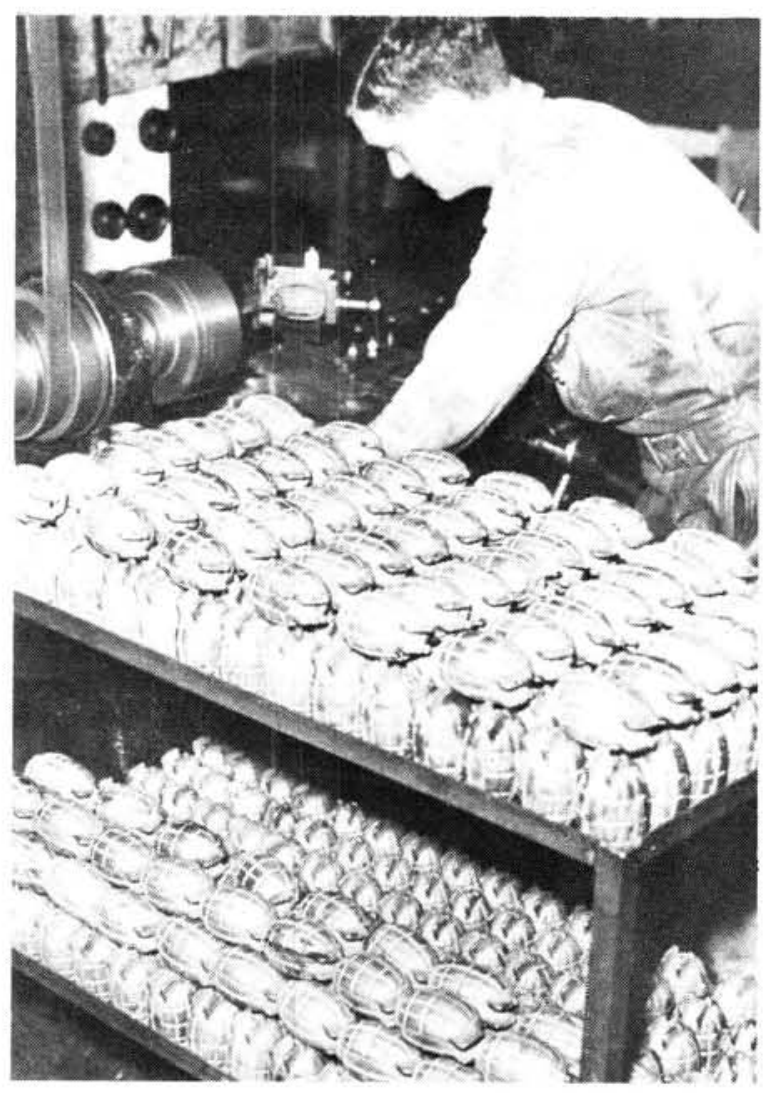

Handgranate in 'n Suid-Afrikaanse fabriek vervaardig 


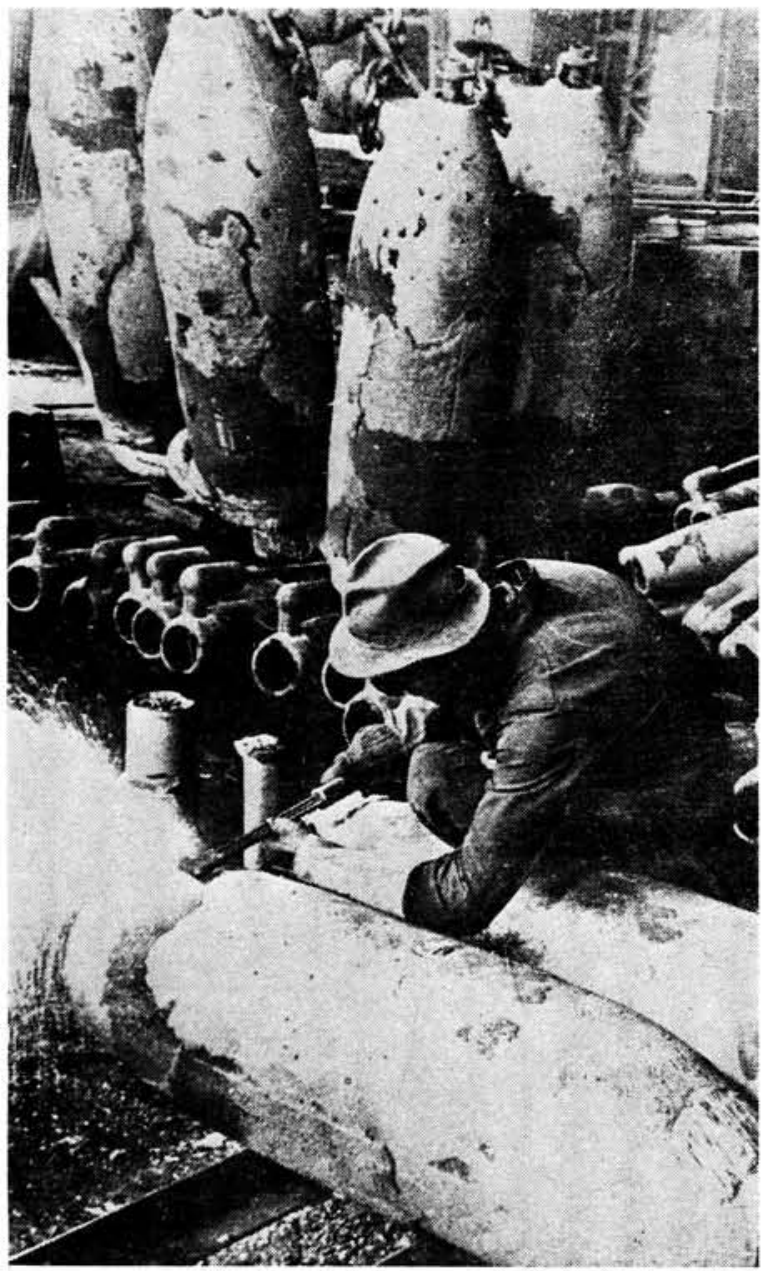

Oorlogsvoorrade: Afwerking van bormme in 'n SuidAfrikaanse gietery

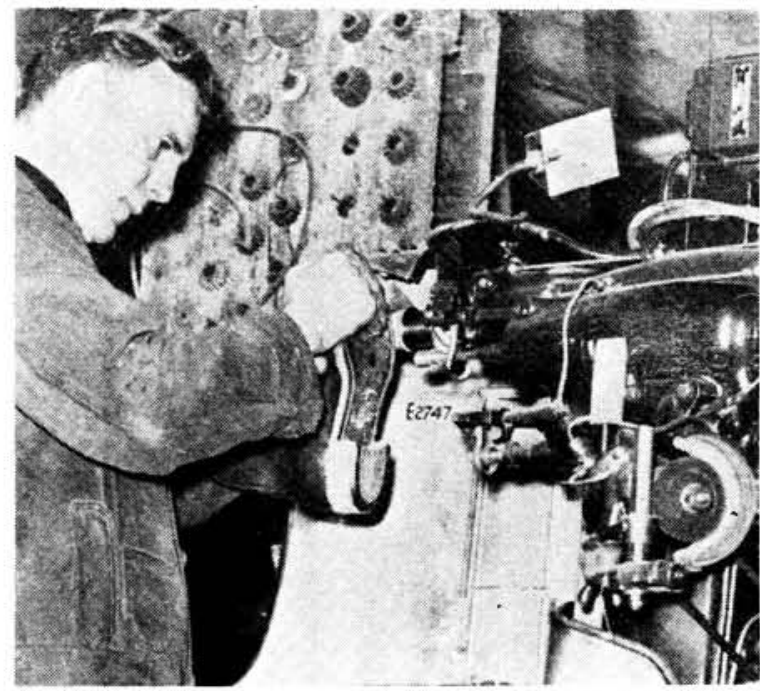

Oorlogsvoorrade: vervaardiging van stewels in 'n Suid. Afrikaanse fabriek
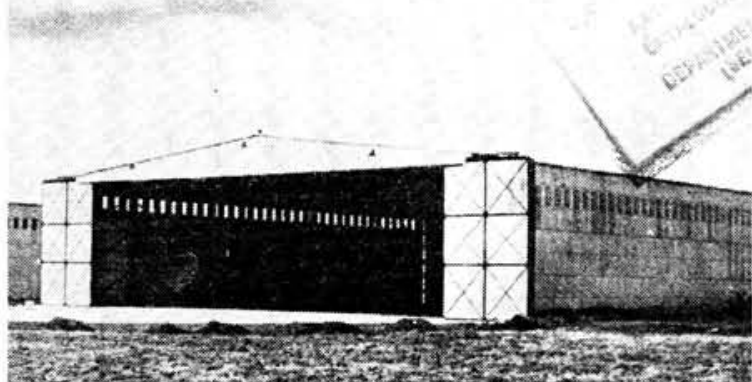

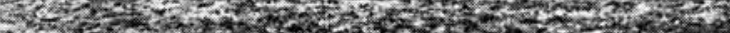
$\rightarrow 20$ -

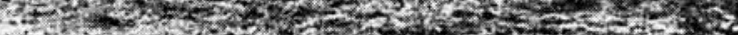

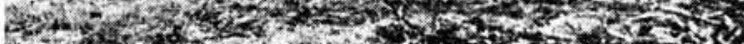

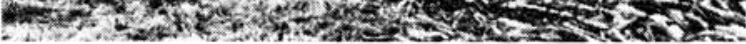
'n Groot aantal staalloodse is vir gebruik in die Unie en vir uitvoer na lande van die oostelike groep vervaardig

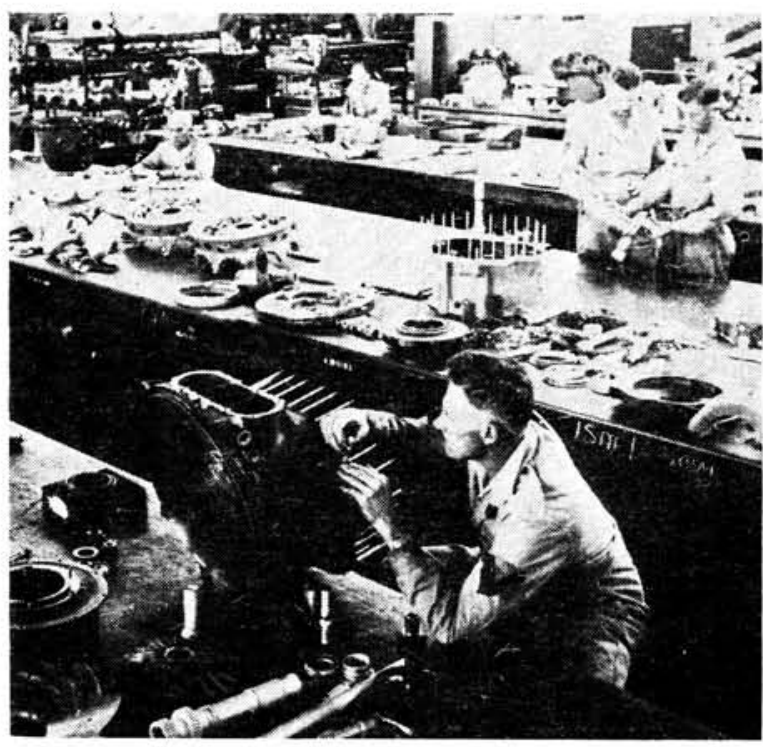

Vervaardiging van onderdele van SALM-vliegtuie

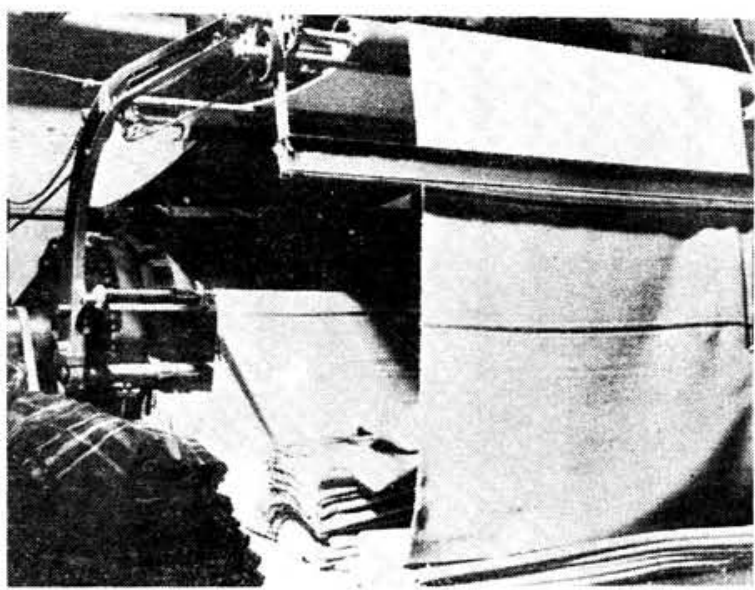

Oorlogsproduksie: vervaardiging van komberse vir die SA Leër 
niese inlingting nodig gemaak, omdat daar dikwels veranderings in die konstruksie van toerusting aangebring is, en omdat alle onderdele van tegniese toerusting ' $n$ hoë graad van verwisselbaarheid moes hê. Daar moes streng aan aflewegingstermyne gehou word en programme kon so te sê oornag verander as omstandighede verander het.

k. Stewels. Die Soldaatstewelkomitee het die produksie van militêre stewels en skoene aangemoedig en gedurende die vyf jaar van die oorlog is 10 miljoen paar vir die UVM, die Britse Voorradeministerie en die Voorsieningsraad van die Oostelike Groep vervaardig. Daarby kom ook nog meer as twee miljoen seilskoene en 90000 rubberstewels en die aansienlik verhoogde produksie van vereenvoudigde (austerity) of utiliteitstipes skoeisel vir burgerlike gebruik.

I. Leërtekstiele. Die Leërtekstielkomitee het die produksie van alle tipes leërkleding en uitrusting vir die Univerdedigingsmag gereël. Die produksie van komberse het $51 / 2$ miljoen bereik, en soveel van hierdie artikels is na die Midde-Ooste en die Oostelike Groep uitgevoer dat die burgerlike bevolking in die Unie inderdaad ongerief in hierdie verband moes uitstaan.

m. Gemeganiseerde vervoeruitrusting. Gemeganiseerde vervoer is uit die staanspoor in die veldtog in Abessinië gebruik, en baie tipes enkeldoelbakke is in SA vervaardig en op ingevoerde onderstelle gemonteer. Danksy ' $n$ groot voor-oorlogse bestelling wat deur die UVM geplaas is, het groot hoeveelhede onderstelle spoedig na SA gekom. Daar is ' $n$ totaal van 32000 voertuie deur die DGWS gemaak: die feit dat 'n groot aantal daarvan in 1940-41 beskikbaar was, het wesenlik tot die spoedige afloop van die Abessiniese veldtog bygedra.

n. Voedsel. Alle soorte voedsel is in groot hoeveelhede aan leërkampe in SA en aan die strydmagte in die verskillende oorlogsgebiede gelewer. Daarby kom nog die grootskaalse proviandering van skepe, wat die posisie in die VK in verband met skepe wat van lewensmiddele voorsien moes word, aansienlik verlig het. Daar is groot hoeveelhede voedsel na die VK en die Voorsieningsraad van die Oostelike Groep, asook aan die leërs van geallieerde regerings in die verskillende oorlogsgebiede, gestuur. ${ }^{20}$
Beskikking oor oorlogsvoorrade. By Oorlogsmaatreël No 99 van 1944 is 'n Beskikkingsraad vir Oorlogsgoed ingestel en deur die Minister van Ekonomiese Ontwikkeling aangestel. Dit het uit 'n voorsitter, vyf lede en 'n sekretaris bestaan. Die opdrag was om oor alle oorlogsvoorrade wat die eiendom van die Unie-regering en oortollig was en, indien dit versoek is, ook oor enige eiendom wat ander regerings in die Unie besit het te beskik. Grond en verbeterings daarop, is by die begrip 'oorlogsvoorrade' ingesluit.

Die Sekretaris vir Verdediging het alle kennisgewings wat oorlogsvoorrade as oortollig verklaar het, aan die Raad voorgelê. Die Raad se beleid insake die beskikking oor sodanige voorrade was om hulle in die eerste instansie aan staatsdepartemente, provinsiale administrasies en ander openbare liggame teen die aankoopprys, plus ' $n$ klein persentasie, toe te ken, tensy hierdie pryse hoër as die heersende markpryse was. Die oorblywende oorlogsvoorrade is aan die publiek teen die geldende markpryse verkoop, by voorkeur op 'n groothandelbasis, of anders is dit teen afgesproke pryse op openbare vendusies opgeveil of na die inwagting van tenders aan die publiek van die hand gesit.

Binnelandse koördinasie tussen DGWS en UVM en ander staatsdepartemente ter verkryging van oorlogsbenodighede het egter nie glad verloop nie. Een van die struikelblokke was dat die besigheidsmetodes en -prosedures van DGWSamptenare verskil het van die metodes waaraan die staatsdepartement gewoond was, en wrywing dus ontstaan het. Volgens Pienaar het die koördinering van werk van die verskillende departemente en organisasies dwarsdeur die oorlog 'n ernstige probleem gebly en die doeltreffendheid van die oorlogspoging benadeel om die volgende redes:

a. Daar was oorvleueling van funksies in die jurisdiksie van die verskillende departemente;

b. ' $n$ Doeltreffende organisasie is nie ingestel om probleme uit te stryk en leiding te gee nie;

c. Die verhouding met vakunies en werkgewersorganisasies was nie duidelik uitgespel nie;

d. Daar was nie veel van georganiseerde arbeid, handel en nywerheid gebruik gemaak nie;

e. Daar was nie 'n duidelik onderskeid tussen advies en uitvoering tov ondergeskikte komitees gemaak nie. ${ }^{21}$ 


\section{Binnelandse handel en beheer}

Beheer oor verbruiksgoedere. Vroeëre beheermaatreëls

Daar is vooruit besef dat die Staat die bevoegdheid sou moes besit om die ekonomiese bedrywigheid van die land in geval van oorlog te beheer, en in April 1939 is die Raad van Beheer oor landsvoorrade binne die Departement van Handel en Nywerheid ingestel met die doel om 'n opname van die land se hulpbronne en van industriële sleutelmanne te maak, en om oor die vorm en omvang van maatreëls te besluit wat geneem moes word om die Unie in geval van oorlog industrieel en kommersieel te beveilig. Onmiddellik na die uitbreek van die oorlog het die Raad wetteregtelike erkenning kragtens die Landsnoodtoestandregulasies ontvang. Hierdie regulasies het aan die Minister van Handel en Nywerheid uitgebreide bevoegdhede verleen om op advies van die Raad die land se ekonomiese hulpbronne en sy potensiaal te reguleer en beheer daaroor uit te oefen en, onder andere

a. om die handel in goedere met behulp van prysbepaling en beheer oor verkope en distribusie, asook beheer oor in- en uitvoer, deur middel van permitte, te reguleer;

b. om opgaring en woekerwins te verhoed;

c. om goedere wat vir publieke en oorlogsdoeleindes nodig is, te vervaardig of op te eis; en

d. om handel met die vyand te verhoed.

Aan alle Staatsministers is die bevoegdheid verleen om enigiemand te verplig om goedere wat skaars was en wat die Staat in die openbare belang nodig gehad het teen ' $n$ redelike prys aan die Regering te verkoop, en om enigiemand wat daartoe in staat was, opdrag te gee om goedere wat in die openbare belang nodig was, binne ' $n$ bepaalde tyd te vervaardig, te verwerk of te behandel.

Voorsiening is ook gemaak vir die aanstelling van 'n Direkteur-generaal van Oorlogsbehoeftes wat beheer sou uitoefen oor die verkryging en produksie van alle goedere wat vir die doeltreffende voortsetting van die oorlog nodig was.

Die Direkteur-generaal van Oorlogsvoorrade het onafhanklik van, maar in noue samewerking met, die Raad van Beheer oor Landsvoorrade opgetree.

Vir die toepassing van die regulasies is die Mandaatgebied Suidwes-Afrika by die Unie ingesluit en ' $n$ raad van drie lede is ingestel om die Raad van Beheer oor Landsvoorrade in daardie gebied te verteenwoordig.

\section{Instelling van algemene beheer.}

Gedurende die eerste twee jaar van die oorlog is daar maar selde van die bevoegdhede van die Minister van handel en Nywerheid gebruik gemaak en die handel en nywerheid het feitlik onbelemmerd met hul normale funksies voortgegaan.

Teen die middel van 1941 het die skaarste aan sekere artikels egter die instelling van meer algemene beheermaatreëls noodsaaklik gemaak.

In Julie is ' $n$ Prioriteitsraad ingestel om die voorrang te bepaal wat aan invoeraansoeke verleen moes word, en 'n Sentrale Adviserende Komitee is in die lewe geroep om as skakel met die handel en nywerheid op te tree en om die Raad van tegniese advies te bedien.

Daar is feitlik onmiddellik, dws met ingang van 15 September, algehele invoer- en uitvoerbeheer deur middel van permitte ingestel en die Sekretaris vir Handel en Nywerheid is as Kontroleur van Invoer en Uitvoer aangestel. Hy is bygestaan deur die invoer- en Uitvoerbeheerraad wat die funksies van die Prioriteitsraad oorgeneem het. Teen Januarie 1942 was Gesamentlike Beplanningsrade besig om ingestel te word met die doel om produksie en die toekenning van krygsgoedere, grondstowwe en skeepsdienste te koördineer. Handelsware wat skaars was, sou gerantsoeneer word om te verseker dat die beste algemene gebruik daarvan gemaak sou word. ${ }^{22}$

\section{Instelling van spesifieke beheer}

By Oorlogmaatreël No 7, wat op 26 Januarie 1942 afgekondig is, is die standaardtipe beheer oor verbruiksgoedere ingestel ingevolge waarvan gespesifiseerde materiaal tot 'beheerde materiaal' verklaar is en die Minister van Handel en Nywerheid magtiging verleen is om kontroleurs met uitvoerende bevoegdhede, onder sy leiding, aan te stel ten opsigte van die handelsartikel waaroor elkeen van hulle beheer sou uitoefen. Die betrokke kontroleur is onder andere daartoe gemagtig om die verkryging, van die hand sit, of gebruik van die beheerde materiaal of die vervaardiging van enige artikel wat die beheerde 
materiaal bevat het, behalwe op voorwaardes wat hy kon stel, te verbied. Die kontroleur is ook daartoe gemagtig om enigiemand wat die beheerde materiaal geproduseer, verkoop of verbruik het of beheer daaroor gehad het, of artikels vervaardig het wat die beheerde materiaal bevat het, te versoek om opgawes van en inligting in verband met die beheerde materiaal en betreffende so 'n persoon se besigheid te verstrek. Hy kon 'n bepaalde persoon beveel om sodanige materiaal aan ' $n$ ander persoon teen betaling van die hand te sit en ook gelas dat aantekeninge gehou en opgawes verstrek moes word. Hy het feitlik die in- en uitvoer van die materiaal onder sy toesig gereguleer, die hoeveelhede vasgestel en in die geval van invoere die voorrang bepaal. Kontroleurs het ook as agente vir die regering opgetree by die aankoop van die noodsaaklike handelsartikels en grondstowwe wat slegs op rekening van regering tot regerng verkry en ingevoer kon word.

Tussen Januarie en April 1942 is sestien soorte verbruiksgoedere tot beheerde materiaal verklaar en kontroleurs oor elke groep aangestel. Hieronder het die volgende goedere geressorteer, soos in sommige gevalle later aangevul:

\section{Yster en staal (met begrip \\ van}

nywerheidsmasjinerie); Leer;

Papier

Masjiengereedskap:

$\begin{array}{ll} & \text { Glasware en } \\ & \text { huishoudelike } \\ \text { benodigdhede: } & \text { Alkohol en melasse; }\end{array}$

Rubber;

Nie-ysterhoudende

materiaal;

Motorvoertuie;

Boumateriaal; Landbougereedskap. -masjinerie en -benodigdhede;

Nywerheidschemikalieë; Mediese en fotografiese benodigdhede: Hout;

Tekstielware;

Die beheer oor bogenoemde verbruiksgoedere het onder die Minister van Handel en Nywerheid geressorteer, maar daarbenewens was daar ook sekere gevalle van onafhanklike beheer, $\mathrm{nl} \mathrm{Be}$ heer oor Nywerheidswerkkragte, Petrolbeheer, Voedselbeheer, Beheer oor die Boubedryf en Prysbeheer.

\section{Unieraad vir die Koördinasie van Voorrade}

Die mening het egter ontstaan dat hierdie toene- mende beheermaatreëls lomp was, dat daar 'n gebrek aan koördinasie was en selfs aan onbehoorlike indiwiduele druk onderworpe was, terwyl dit ook voorgekom het asof die oorheersende prioriteit van oorlogsbehoeftes te min rekening met die ewe belangrike dog minder opvallende behoeftes van die burgerlike bevolking gehou het. Die Administrasie van die VSA het egter nie eintlik met laasgenoemde mening saamgestem nie; sendings is gedurende $\mathrm{Mei}$ Augustus 1942 uit Amerika gestuur om op "n grondslag van 'noodsaaklikheid' die behoeftes van die Unie en die Rhodesiës te bepaal, en veral om die Amerikaners gerus te stel dat, wat die toekenning van voorrade betref, die goudmynbedryf nie voorkeur bo en ten koste van wat die Amerikaners as meer 'essensiële' regstreekse oorlogsbedrywe beskou het, geniet nie. Om die Verenigde State se kritiek oor die hantering van beheer oor 'eindgebruik' voor te spring, het die Eerste Minister in April 1942 die Unieraad vir die Koördinasie van Voorrade binne die Departement van Handel en Nywerheid ingestel om die vraag en aanbod te koördineer, om voorrade van noodsaaklike goedere in die Unie vas te stel, en om die gelyke verdeling van die beskikbare voorrade tussen oorlogsbehoeftes en die noodsaaklike behoeftes van die gemeenskap te verseker. Dit was 'n erkenning daarvan dat die maatreëls om samewerking tussen die kontroleur van verbruiksgoedere en die invoer-en uitvoerbeheerorganisasies te bewerkstellig, 'n mislukking was en tegelykertyd ook 'n poging om die owerhede in die VSA en die VK te oortuig daarvan dat, met die voorlegging van die lys van benodigdhede, Suid-Afrika 'n allesomvattende beeld van sy behoeftes gegee het wat op 'n uiterste oorlogspoging gegrond was.

Die Unieraad vir die Koördinasie van Voorrade het ten doel gehad om die werk van 'n uitklaringsinrigting te verrig waar al die maatreëls wat in verband met beheer getref is, gekoördineer kon word. Om dié rede het dit al die kontroleurs (van sowel verbruiksgoedere as funksies en dienste soos prysbeheer oor werkkragte) tesame met verteenwoordigers van 'n verskeidenheid van departmente ingesluit sodat die lede daarvan altesame min of meer dertig getel het. Hierdie raad was te groot en te lomp om vinnig en met beslistheid op te tree, en dit het gou feitlik magteloos geword, maar twee klein komitees wat daarmee geassosieer was, het bly voortbestaan, nl:

\section{a. Binnebeheerkomitee.}

Die Binnebeheerkomitee (Inner Control Com- 
mittee) is ingestel om oor regstreekse oorlogsbehoeftes toesig te hou wat prioriteit betref, en om meningsverskille tussen die kontroleurs van verbruiksgoedere aan die een kant en die Departement van Verdediging, die DGWS en die Spoorweg-administrasie aan die ander kant op te los. As 'n natuurlike gevolg hiervan moes die Komitee ook die verantwoordelikheid aanvaar om in gevalle van ernstige tekorte aan benodigdhede vir die burgerlike bevolking, handelend op te tree.

\section{b. Koördinerende Komitee vir Nywerheidsbe- hoeftes.}

Die Koördinerende Komitee vir Nywerheidsbehoeftes is ingestel om met die herontwikkeling van SA se nywerhede behulpsaam te wees en om te sorg dat die nywerhede hul produksie op doeltreffende wyse tot essensiële behoeftes, sowel militêr as burgerlik, sou beperk. Verder was dit ook die Komitee se plig om die instandhouding van grondstofvoorrade te verseker en om verkwisting uit te skakel. ${ }^{23}$

Die Nasionale Voorsieningsraad is in Oktober 1942 in die lewe geroep in die plek van die Unieraad wat ' $n$ te lompe organisasie was, maar ook hierdie raad se voortbestaan was van korte duur. Die Nasionale Voorsieningsraad se verval tot onaktiwiteit het die belangrikheid van die uitvoerende hoof, dws die Direkteur-generaal van Voorrade, verhoog, en uitgebreide bevoegdhede, onderworpe aan die toesig van die Eerste Minister, is aan hom verleen. Hy het al die bevoegdhede wat aan hom in sy hoedanigheid van Direkteur-generaal in verband met oorlogsbe. hoeftes verleen is behou, dws hy het voortgegaan om beheer oor die verkryging en produksie van benodighede, oor opeising en die uitreiking van bevele om te produseer, uit te oefen. Maar hierdie bevoegdhede is verder uitgebrei om alle beheerde verbruiksgoedere in te sluit. Daarby het hy ook uitgebreide gesag in verband met die toekenning van voorrade verkry. Die bevoegdheid om in- en uitvoer te reël is ook aan hom toevertrou. Verder is hy ook gemagtig om amptenare aan te stel en liggame in die lewe te roep wat hy nodig sou hê om hom in sy taak behulpsaam te wees. Die kantoor van die Direkteurgeneraal van Oorlogsvoorrade en die Raad van beheer oor Invoer en Uitvoer het opgehou om te bestaan. Hul funksies, asook dié van die bestaande organisasies vir die beheer van verbruiksgoedere, is deur die Direkteur-generaal van Voorrade oorgeneem en onder ' $n$ verenigde bestuur geadministreer.

Sekere beheerliggame wat buite die ingelyste organisasies vir die beheer van verbruiksgoedere ontwikkel het, is nie by die bepalings van Oorlogsmaatreël No 146 ingesluit nie. In SuidAfrika was die betrokke liggame dié wat funksionele beheer oor pryse, werkkragte, die boubedryf en die verbruiksgoedere, petrol en voedsel uitgeoefen het.

\section{Direktoraat vir Burgerlike Bevoorrading}

In Julie 1943 is die Direktoraat vir Burgerlike Bevoorrading omskep in ' $n$ koordinerende voorsieningdirektoraat vir verbruiksgoedere met vier gekose lede wat regstreeks aan die Direkteurgeneraal verantwoordelik was om toe te sien dat die beheerstelsel wat kragtens Oorlogsmaatreël No 149 van 1942 ingestel is in ooreenstemming met die beleid van die Regering sou bly. Saam met ander belangrike pligte is aan hulle opdrag gegee om die werk van die kontroleurs van verbruiksgoedere te koördineer, om SA se in- en uitvoer te bestuur en om nouer samewerking met alle ander vertakkings van die Direkteur-generaal van Voorrade se organisasie, staatsdepartemente en die kontroleurs wat nie by die organisasie ingesluit is nie, te bewerkstellig

\section{Voorraderaad}

Die Voorraderaad, waaronder die Voorsieningdirektoraat vir Verbruiksgoedere gefungeer het, was egter die nuwe uitvoerende liggaam van die Direkteur-generaal van Voorrade. Hierdie Raad was invloedryk en het baie belange en uitgebreide industriële, kommersiële en administratiewe ondervinding verteenwoordig. Onder die Voorraderaad is die volgende komitees in die lewe geroep:

a. Die Komitee vir Invoer en Uitvoer verantwoordelik vir die koördinasie van en beheer oor handelsartikels wat in of uitgevoer moes word, en die uitreiking van invoer- en uitvoerpermitte en sertifikate van noodsaaklikheid.

b. Die Uitvoerende Komitee van Kontroleurs om die werk van die kontroleurs van handelsartikels te koördineer en in die algemeen aan die Raad verantwoordelik te wees vir die toepassing van beheer oor handelsartikels

c. Die Nywerheidskomitee, met die funksie om die Raad in verband met nywerheids- 
vraagstukke van advies te dien en om met ander afdelingsproduksiekomitees soos die Munisieproduksiekomitee, die Leërtekstielkomitee en die Komitee vir Militêre Stewels oorleg te pleeg en saam te werk.

Die kontroleurs van verbruiksgoedere het nou aan die Voorraderaad verantwoordelik geword en was aan die Raad se instruksies onderworpe. Die Sentrale Adviserende Komitee is afgeskaf, maar die Binnebeheerkomitee het met sy werk voortgegaan as die finale appelhof in verband met verskepingsprioriteit.

Die organisasie van die spanstelsel het baie geleenthede gebied om betrekkinge met nywerheids- en handelskringe aan te knoop. Die streekkomitee vir verbruiksgoedere in elke handels- en nywerheidsentrum wat redelik groot was, het ' $n$ verteenwoordiger gestuur na een van die nege sonekomitees waaronder die land ingedeel is, en een lid is uit elkeen van hierdie nege komitees gekies om die nasionale span vir die betrokke handelsartikel te vorm. Al hierdie belange is op die Voorraderaad, waarvan die lidmaatskap nie tot amptenare van die Direkteurgeneraal van Voorrade beperk was nie, verteenwoordig. Die Voorraderaad het ook die vernaamste uitvoerende amptenare van die Direkteur-generaal van Voorrade bevat, wat die beslissings sou moes uitvoer. Dit was dus 'n koördinerende raad; ' $n$ raad wat die beleid wat gevolg moes word, voorgeskryf het. Die Raad het uit slegs twaalf lede bestaan wat elkeen meer as een belang verteenwoordig het, en om dié rede het dit nooit lomp en onhanteerbaar geword nie, soos wel met die Nasionale Voorraderaad die geval was. Tot aan die einde van die oorlog het die raad elke veertien dae vergader. Die mate van beheer wat werklik deur die kontroleur van verbruiksgoedere uitgeoefen is, het van die behoeftes op daardie oomblik en van die skaarste en noodsaaklikheid van die betrokke materiale afgehang. ${ }^{24}$

Verslapping van beheer. Die eerste stappe met die oog op die verslapping van beheer is in afwagting van die end van die oorlog gedoen, maar verslapping kon slegs geleidelik geskied. Die vervaardigingsnywerhede kon nie onmiddellik van oorlogstydse na vredestydse produksie oorskakel nie, die agterstand wat burgerlike behoeftes betref, was besonder groot en grondstofvoorrade en vervaardigde goedere het oor die algemeen skaarser geword toe die einde van die oorlog nader, aangesien voorrade vir die verligting van vernietigde gebiede nodig was. Skeepsruimte het lank na die staking van aktiewe vyandelikhede nog beperk gebly.

Kragtens Oorlogsmaatreël no 75 het die bevoegdhede van die Direkteur-generaal van Voorrade ten opsigte van beheerde materiaal en inen uitvoere weer oorgegaan na die Departement van Handel en Nywerheid wat op 26 Oktober 1945 die bestaande Afdeling Landsvoorrade oorgeneem het. Beheer is afgeskaf sodra omstandighede dit toegelaat het, maar twee jaar na die oorlog het daar nog ' $n$ paar vorms van beheer van krag gebly.

Ander Beheer - Prysbeheer. Een van die ernstigste gevolge van die Eerste-Wêreldoorlog was die skerp styging in pryse wat teen die einde daarvan en ook daarna plaasgevind het en die daaropvolgende ineenstorting van hierdie pryse in die vroeë twintigerjare. Gedagtig hieraan was die meeste lande met die uitbreek van die Tweede Wêreldoorlog vasberade om pryse onder beheer te hou. Een van die eerste maatreëls na die uitbreek van die oorlog was die uitvaardiging van die Landsnoodtoestandregulasies in September 1939, wat die instelling van die Raad van Beheer oor Landsvoorrade ingesluit het. Een van die funksies van hierdie liggaam was om pryse in die Unie te beheer, en dit het hy dan ook byna twee jaar lank gedoen.

Toe Suid-Afrika tot die oorlog toegetree het, is die pryse van sekere landbouprodukte op aanbeveling van die Beheerrade vasgestel. Die stelsel het feitlik onveranderd gebly en is inderdaad gedurende die oorlogsjare uitgebrei. Die beheer deur die Raad van Beheer oor Landsvoorrade en later deur die Pryskontroleur uitgeoefen, was egter nooit allesomvattend nie. ${ }^{25}$

Regulasies waarvolgens prysbeheer ingestel is, kan in twee kategorieë verdeel word. Die eerste het die Minister van Handel en Nywerheid gemagtig om, op aanbeveling van die Raad van Beheer oor Landsvoorrade, maksimum pryse vir goedere te bepaal. Tweedens was regulasies van krag op goedere waarvan die pryse nie vasgestel is nie, wat bepaal het dat winste op sulke goedere beheer is deur middel van ' $n$ algemene prysformule wat voorgeskryf het dat die verkoper van enige goedere nie ' $n$ hoër winspersentasie op die werklike koste van die goedere kon maak as die persentasie wat op soortgelyke goedere voor 22 Aug 1939 gemaak is nie. ${ }^{26}$

Op 7 Oktober 1939 is die pryse van baie van die 
noodsaaklikste voedselsoorte en huishoudelike benodigdhede bevries. Op 1 Desember is spesifieke maksimum pryse vir 'n groot aantal verdere voedselsoorte en noodsaaklike huishoudelike benodigdhede vasgestel.

Vroeg in die oorlog het handelaars die vraag geopper of winste op die grondslag van die werklike koste of op dié van die vervangingswaarde vasgestel moes word. As ' $n$ kompromis het die Raad ingestem dat handelaars, vir die toepassing van winsbeheer, toegelaat kon word om die gemiddelde van die werklike koste en die vervangingskoste te bereken.

Dit was die Raad se beleid om prysbeheer so min moontlik as wapen to gebruik, maw om pryse vir slegs ' $n$ beperkte aantal artikels, veral noodsaaklikes, te bepaal. Namate tekorte ontstaan het, het die aantal huishoudelike artikels waarvoor die Raad die kleinhandelpryse vasgestel het, nogtans onvermydelik toegeneem. Daarbenewens het groothandel- en fabriekspryse onder die Raad se toesig gekom deurdat dit op ' $n$ winspersentasiegrondslag geplaas is.

Vir toepassing van prysbeheer het die Raad gebruik gemaak van plaaslike komitees onder voorsitterskap van landdroste, verteenwoordigers van plaaslike belangegroepe wat klagtes ontvang het en saam met aanbevelings deurgestuur het. Daarbenewens is prysbeheerinspekteurs in verskillende gebiede benoem om teen prysmisbruik te waak.

Teen die middel van 1941 het dit begin blyk dat die bestaande maatreëls onvoldoende was om die steeds toenemende ingewikkeldhede as ' $n$ deeltydse taak via die Raad te laat hanteer, en $n$ twee jaar is daar toe oorgegaan na 'n pryskontroleur-organisasie.

Die Pryskontroleur wat in Augustus 1941 aangestel is, het die taak gehad om die prysbeheeradministrasie te reorganiseer en uit te brei. Opsigters is in die vernaamste sentrums van die Unie benoem ten einde toesig oor pryse in hul gebiede te hou en as voorsitters van die plaaslike komitees op te tree, wat uit drie verteenwoordigers van die sakegemeenskap en drie van die verbruikers bestaan het. Daar is groter gebruik gemaak van die span beroepsrekenmeesters in die personeel wat deur die Raad van Beheer oor Landsvoorrade aangestel is om die vasstelling van koste en pryse te ondersoek en om metodes uit te werk waarvolgens pryse wat vir beide die produsent en die verbruiker billik sou wees, bereken kon word.

Bestaande bevoegdhede is deur die Pryskontroleur oorgeneem en die volgende nuwe bevoegdhede aan hom verleen:

a. Hy kon maksimm pryse vir sekere dienste bepaal, soos bv vir haresny, wasserywerk, ens

b. Hy het hotel- en losieshuistariewe beheer, wat hy ongeveer $7 \frac{1}{2}$ persent hoër as die tariewe van 1 September 1939 vasgestel het.

c. Hy het maatreëls getref teen die verhoging van koste as gevolg van tussen-groothandel.

d. Die faktorstelsel is by Goewermentskennisgewing ingevoer. In plaas daarvan om handelaars toe te laat om dieselfde winsmargeof handelspellingspersentasie ('mark-up' persentasie) by goedere waarvan die prys gestyg het, by te voeg - en dus hul bruto wins in dieselfde verhouding te verhoog as wat pryse gestyd het, - is die toelaatbare 'handelspeling of winsmarge' deur ' $n$ faktor verminder wat afgeneem het na gelang die kospryse gestyg het. Die faktortabelle hiervoor is van tyd tot tyd hersien.

Om dit onnodig te maak dat nuwe pryse vir alle bestaande voorrade vasgestel word, is hierdie stelsel slegs op goedere wat na 15 Oktober in voorraad geneem is, van toepassing gemaak, en is die wettige maksimum pryse van alle goedere wat op 15 Oktober 1941 voorradig was, bevries.

Uiteindelik was daar verskeie metodes van prysbepaling wat deur die Pryskontroleur toegepas is, $\mathrm{nl}$ die vasstelling van maksimum pryse; die bevriesing van pryse; die vasstelling van persentasiemarges; en die gebruik van die basiese faktor en die standaardfaktor, wat 'n alternatief vir laasgenoemde was. Die standaardfaktor het 'n taamlik omvattende lys handelsartikels gedek, waarvoor dit ' $n$ toelaatbare of standaardwinsfaktor voorgeskryf het. Dit is oorspronklik bedoel vir handelaars met ontoereikende of geen vooroorlogse rekord nie, maar is mettertyd deur die meeste handelaars gebruik. Daar was ook ' $n$ stelsel van standaardwinsmarges of -handelspelings (standaard 'mark-ups') wat, by die kosprys bygevoeg kon word.

Prysbeheer het nou alle fabrieks-, groothandelen kleinhandelpryse gedek en ook baie soorte dienste. ' $n$ Klein aantal landbouprodukte is ook binne die bestek daarvan gebring, ò deur middel van vasgestelde prysmarges ò deur maksi- 
mum pryse, soos bv in die geval van aartappels en eiers.

\section{Waardeskatting van prysbeheer in Suid- Afrika}

Die fundamentele doel van prysbeheer in SuidAfrika was om woekerwins en die uitbuiting van die publiek te voorkom. Dit kon nie prysstygings verhoed nie, aangesien binnelandse pryspeile deur pryse in die buiteland beïnvloed word. Dit geld veral van Suid-Afrika, wat op groot skaal sowel goedere as grondstowwe invoer. Prysbeheer kon egter, en het ook, 'n ongeregverdigde styging van pryse in verhouding tot koste voorkom. Daar kan dus gesê word dat prysbeheer in Suid-Afrika in dié mate geslaagd was. Hoë pryse as sodanig was nie noodwendig onverenigbaar met prysbeheer nie, terwyl lae pryse slegs verseker kon word deur pryse te subsidieer, soos in die VK in die geval van noodsaaklike handelsartikels en Suid-Afrika met brood gedoen is. ${ }^{27}$

Petrolbeheer. In Groot-Brittanje is petrolrantsoenering op die eerste dag van die oorlog ingestel. Gedurende 1941 en 1942 het die Verenigde Koninkryk herhaaldelik aan die Unie-regering voorgestel dat beperkings op die verbruik van petrol in die Unie opgelê moet word. Die Unie-regering was egter nie geneë om dit te doen nie. Daar is gemeen dat strenge besnoeiings in ' $n$ land met ylbevolkte gebiede en groot afstande onwenslik sou wees. (Dit sou ook ongewild gewees het).

Daar is eers ' $n$ poging aangewend om te besuining deur ' $n$ beroep op verbruikers te doen om vrywilliglik minder petrol te gebruik, maar dit het nie geslaag nie. Staatsbeheer het toe 'n aanvang geneem met Proklamasie No 1672 van Oktober 1941 wat die verkoop van petrol tussen $12 \mathrm{~nm}$ op Saterdag en 6 vm op Maandag verbied het. Ook hierdie stap was vrugteloos; die statistiek vir petrolverbruik na hierdie Proklamasie het min verandering getoon.

Die Unie se olievoorrade het in vredestyd hoofsaaklik uit die Midde-Ooste gekom (52 persent), maar ook uit Venezuela (27 persent) en Nederlands-Oos-Indië (20 persent). Hierdie bronne is almal deur die uitbreiding van die oorlog na die Midde-Ooste as gevolg van Japan se toetrede tot die oorlog, en deur die afwending van Venezuela se olie na Groot-Brittanje geraak.

Met die toetrede van die Verenigde State tot die oorlog is die toekenning van olievoorrade en die bepaling van tenkskiproetes onder die beheer van die 'Combined Shipping Adjustment Board' geplaas wat 'n gesamentlike Brits-Amerikaanse raad was en in Januarie 1941 in Washington, met ' $n$ tak in Londen ingestel is. Vir die Unie was daar geen ander uitweg nie as om ' $n$ stelsel van petrolrantsoenering in te stel. Dit is gedoen by Oorlogsmaatreël no 3 van 1942 wat op 2 Februarie 1942 in werking getree het.

Petrolrantsoenering. Die Unie se rantsoeneringstelsel het ' $n$ vaste basiese-rantsoen per maand vir alle gelisensieerde private motoriste voorgeskryf. Aanvullende toekennings is gemaak waar grondige redes daarvoor aangevoer kon word. Die rantsoen vir motors is volgens gewig en dié vir motorfietse volgens perdekrag toegeken, en ' $n$ tabel is opgestel om die petrolverbruik van 'n voertuig daarvolgens te bereken. Die basiese rantsoen is aanvanklik op ' $n$ grondslag van 400 myl per maand vasgestel en was slegs op op private motoriste van toepassing. Daarna is die afstand tot $300 \mathrm{myl}$ per maand verminder en uiteindelik, in Desember 1942, tot 200 myl per maand. In September 1944 is dit onwettig verklaar om meer as $75 \mathrm{myl}$ sonder ' $n$ spesiale permit te ry. Intussen is die stelsel ook na die handelsvervoer uitgebrei. Daar is bepaal dat die handelsvervoer slegs aanvullende toekennings sou kry, aangesien sulke toekennings strenger beheer kon word. Sodoende is petrolverbruik veral in die privaatsektor sodanig verminder dat verbruik in die privaathandel bv oor die tydperk 1941-43 met $31 \%$ en dié van staatsdepartemente met $8 \%$ verminder het, teenoor 'n toename van $58 \%$ in Verdediging en $1,5 \%$ by SAS \& $\mathrm{H}^{29}$

Die petrolkontroleur wat in beheer van die skema gestaan het was in Pretoria gevestig, terwyl plaaslike landdroste as die distrikspetrolkontroleurs met die hulp van spesiale distrikkontroleurs in groter stede, verantwoordelik was vir uitreiking van permitte en oorweging van aansoeke vir aanvullende toekennings.

Petrolkoepons. Met die medewerking van die Posmeester-generaal is die werklike uitreiking van petrolkoepons dwarsdeur die Unie in plaaslike poskantore gedoen, wat elke maand tussen die $6 \mathrm{de}$ en die $16 \mathrm{de}$, op vertoning van die permit geskied het.

Streng reëls is ook voorgeskryf vir garages wat petrol aan die publiek verskaf het. Petrol kon slegs in die tenk van die voertuig gegooi word waarvan die nommer op die koepon voorgekom het, en die vereiste aantal koepons moes oor- 
handig word vir die hoeveelheid petrol wat gekoop is. Aan die einde van elke maand het garage-eienaars hul opgehoopte koepons aan die Oliegroep gestuur, wat as algemene agente vir die verspreiding van petrol op groot skaal opgetree het.

\section{Oliegroep-skakelkantoor (OGLO).Die vier} grootste invoermaatskappye het vroeg in die oorlog saamgewerk om hul opbergingsfasiliteite te verpoel, maar hulle het voortgegaan om hul produkte onder hul eie handelsname te verkoop. OGLO het ' $n$ verteenwoordiger in die personeel van die Petrolkontroleur se hoofkantoor gehad en dit was sy plig om maandelikse opgawes van die beskikbare petrolvoorrade in die land voor te lê. Beramings van die Unie se petrolbehoeftes is vir drie, ses en twaalf maande vooruit opgestel en aan die Tenkskeepsrade in Londen en Washington gestuur.

Die statistieke toon dat die hoeveelheid petrol wat gedurende die tydperk 1942-46 voorradig was, selde vir langer as drie maande genoegsaam was (teen die verminderde verbruik ten gevolge van rantsoenering). Die Britse regering het aanvanklik gehoop dat dit vir SA moontlik sou wees om 'n genoegsame hoeveelheid petrol vir ses maande in voorraad te hou. Hierin is daar egter nooit geslaag nie, hoofsaaklik weens 'n tekort aan toereikende opbergingsfasiliteite.

Verslapping van petrolbeheer. Die beëindiging van die oorlog in Europa en in die Verre Ooste het geen onmiddellike verligting van die algemene petroltoestand teweeggebring nie. Die Britse regering het daarop aangedring dat SA petrolbeheer moes behou totdat Brittanje se tenkvloot weereens vir SA se gebruik beskikbaar was. Dit sou dollars bespaar en die las op die sterlinggebied verlig. Die Unie-regering het egter die Amerikaanse oliemaatskappye se aanbod vir die onmiddellike invoer van petrol aangeneem (22 Desember 1945).

In opdrag van die Minister van Handel en Nywerheid het die Petrolkontroleur die publiek 'n 'Kersgeskenk' gegee deur die basiese rantsoen vir dié maand en ook die volgende maand tot 300 myl te verhoog. In Februarie 1946 het 'n verdere bonus gevolg toe die afstand tot $400 \mathrm{myl}$ verhoog is en die 75 myl-grens vir motoriste, wat sedert 29 September 1944 van krag was, opgehef is. Alhoewel die petrolposisie in Suid-Afrika af en toe moeilik was, het dit nooit uiters swak geword nie.
Voedselbeheer. Voedselbeheer was hoofsaaklik deur middel van die stelsel van beheerrade wat onderhewig aan die Bemarkingswet ingestel is, gehanteer. Waar hierdie liggame vooroorlogs merendeels te doen gehad het met die afset van surplusse in die buiteland was hulle in die oorlogsjare in die algemeen meer toegespits op handhawing en stimulering van produksie in die aangesig van afnemende aanbod teenoor toenemende vraag, en alternatiewelik die ontginning van alternatiewe afsetmoontlikhede, byvoorbeeld van vrugte en wol wat tradisioneel na Britse markte gevloei het. Die produksie van mielies, koring en wol is agv droogtes en ander probleme tydens die oorlogsjare tot so 'n mate nadelig beinvloed dat in teenstelling met groot vooroorlogse uitvoersurplusse $4 \frac{1}{2} 2$ miljoen sakke mielies selfs van Argintinië in 1946-47 ingevoer moes word. Alhoewel daar dus ook tydelike tekorte in sekere voedselsoorte ontstaan het, het die posisie nooit so kritiek geraak dat verdere werklike beheermaatreëls nodig geword het nie. $^{30}$

Boubeheer. Beheer oor die boubedryf is op ' $n$ relatief-vroeë stadium nl Julie 1941 vir die eerste keer ingestel met die oogmerk om privaatbouwerk wat met die oorlogsbehoeftes sou bots te beperk. Onderhewig hieraan is die oprigting verandering en herstel van geboue onder 'n maksimum waarde van R4000 (wat later verminder is tot ' $n$ maksimum van R500) sonder goedkeuring van die Kontroleur verbied. Aparte maatreëls het gegeld tov beheer oor boumateriaal soos toegepas deur die PWD-distrikverteenwoordigers wat as boumateriaalkontroleurs ageer het, en bou beheer soos toegepas deur die Minister van Openbare Werke as kontroleur van bouwerke. Hierdie organe het in noue skakeling doeltreffende beheer oor die bedryf uitgeoefen. Bouwerke vir verdediging het algehele voorkeur geniet en behuising tweede prioriteit hoewel dit baie beperk was in ooreenstemming met die hoeveelheid materiaal veral timmerhout wat beskikbaar was. Met die instelling van boubeheer op 9 Julie 1942 is beheer oor boumateriaal ietwat verslap. Die Kontroleur van Boumateriaal het dit moontlik gevind om artikels geleidelik van beheer vry te stel en slegs sleutelartikels waaraan daar nog 'n tekort was, op die lys te hou, aangesien verbruik deur die Boukontroleur beheer is. Aansoeke om permitte vir bouwerk en gebruik van skaars materiale is dus geleidelik verslap soos die toestand verbeter het. Boubeheer het egter tot lank na die oorlog voortgeduur voordat dit geleidelik verslap is namate die voorradeposisie verbeter het. ${ }^{31}$ 
Verdedigingsbouwerk het soos vermeld voorkeur bo alle ander geniet. Eers nadat daar in Verdedigingsbehoeftes voorsien is, kon arbeid en materiaal vir ander bouwerk aangewend word. Die bedrae wat aan verdedigingsbouwerk bestee is, vergeleke met nie-verdedigingsbouwerk, was gedurende die tydperk $1939-45$ soos volg: ${ }^{31 a}$

Nie-

\begin{tabular}{|c|c|c|}
\hline & Verdediging & verdediging \\
\hline & $£$ & $£$ \\
\hline $1940-41 \ldots$ & 10260,000 & 15200,000 \\
\hline $1941-42 \ldots$. & 12100,000 & 10800,000 \\
\hline $1942-43 \ldots$. & 10240,000 & 13500,000 \\
\hline $1943-44 \ldots$ & 5000,000 & 23800,000 \\
\hline $1944-45 \ldots$ & 3000,000 & 26800,000 \\
\hline 1945 & - & 49700,000 \\
\hline
\end{tabular}

*Dr J. vd B. Breedt is verbonde aan die Departement Ekonomie, Universiteit van Suid-Afrika. Hy was voorheen verbonde aan die Militêre Akademie Saldanha.

\section{Verwysings}

1. S.M. van Dyk. Die Ekonomiese Oorlewingspotensiaal van Suid-Afrika, ongepubliseerde MComm-verhandeling, RAU, Des 79, p. 9. 1a. Derde Interimverslag va die Kommissie insake Industriële- en Landboubenodighede, Staatsdrukker, Pretoria, p. 1617.

2. Union War Histories, Civil Section Documents, Lys 1, Vol 1, Leêr Nr 12. p. 35.

3. a.w., p. 45 .

3a. a.w., p. 48.

4. a.w., p. 59.

5. a.w., p. 55

6. a.w., p. 64 .

7. Offisiële Jaarboek van die Unie van Suid-Afrika, No 29-1956/57. Staatsdrukker, Pretoria (hierna genoem Jaarboek) p. 809.

8. Jaarboek, p. 810.

9. Jaarboek, p. 816

10. E. Pienaar: Enkele Ekonomiese Aspekte van die voorsiening van krygsvoorrade aan die Unieverdedigingsmag met spesiale verwysing na die produksie van krygsvoorrade in die Unie van Suid-Afrika gedurende Wêreldoorlog II, Ongepubliseerde D Commverhandeling, U.P. 1964, p. 18.

11. Jaarboek, p. 818

13. Pienaar, E., a.w. p

14. Jaarboek, p. 819

15. Jaarboek, p. 845 .

16. Union War Histories, Civil Section Documents, Lys 1, Vol 1, Lêer Nr 146, p. 172

17. a.w., p. 159

18. a.w., p. 173

19. a.w., p. 159

20. Jaarboek, p. 822

21. Pienaar, E., a.w., p. 142.

22. Jaarboek, p. 824

23. Jaarboek, p. 825

24. Jaarboek, p. 827.

25. Jaarboek, p. 828

26. SA Journal of Economics, Vol 8, No 4 Desember 1940.

27. Jaarboek, p. 829.

28. a.w., p. 831

29. a.w., p. 832

30. a.w. p. 858

31. a.w., p. 871

31a. a.w., p. 870 